Old Dominion University ODU Digital Commons

2018

\title{
Coordination of Different Ligands to Copper(II) and Cobalt(III) Metal Centers Enhances Zika Virus and Dengue Virus Loads in Both Arthropod Cells and Human Keratinocytes
}

Shovan Dutta

Old Dominion University

Michael J. Celestine

Old Dominion University, mcelesti@odu.edu

Supreet Khanal

Old Dominion University

Alexis Huddleston

Old Dominion University

Colin Simms

Old Dominion University

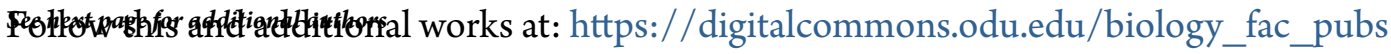

Part of the Biochemistry Commons, Biophysics Commons, $\underline{\text { Cell Biology Commons, Molecular }}$ Biology Commons, and the Virology Commons

\section{Repository Citation}

Dutta, Shovan; Celestine, Michael J.; Khanal, Supreet; Huddleston, Alexis; Simms, Colin; Arca, Jessa Faye; Mitra, Amlam; Heller, Loree; Kraj, Piotr; Ledizet, Michael; Anderson, John F.; Neelakanta, Girish; Holder, Alvin A.; and Sultana, Hameeda, "Coordination of Different Ligands to Copper(II) and Cobalt(III) Metal Centers Enhances Zika Virus and Dengue Virus Loads in Both Arthropod Cells and Human Keratinocytes" (2018). Biological Sciences Faculty Publications. 332.

https://digitalcommons.odu.edu/biology_fac_pubs/332

\section{Original Publication Citation}

Dutta, S., Celestine, M. J., Khanal, S., Huddleston, A., Simms, C., Arca, J. F., .. Sultana, H. (2018). Coordination of different ligands to copper(II) and cobalt(III) metal centers enhances zika virus and dengue virus loads in both arthropod cells and human keratinocytes. Biochimica Et Biophysica Acta-General Subjects, 1862(1), 40-50. doi:10.1016/j.bbagen.2017.10.004 


\section{Authors}

Shovan Dutta, Michael J. Celestine, Supreet Khanal, Alexis Huddleston, Colin Simms, Jessa Faye Arca, Amlam Mitra, Loree Heller, Piotr Kraj, Michael Ledizet, John F. Anderson, Girish Neelakanta, Alvin A. Holder, and Hameeda Sultana 


\section{Accepted Manuscript}

Coordination of different complexes to copper(II) and cobalt(III) metal centers enhances Zika virus and dengue virus loads in both arthropod cells and human keratinocytes

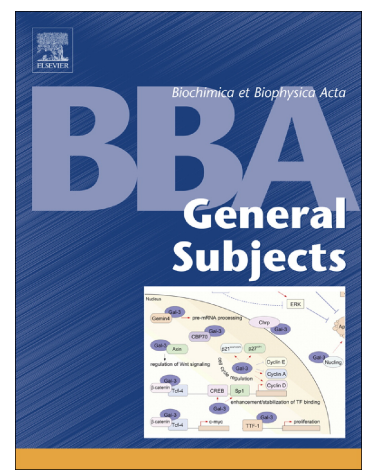

Shovan Dutta, Michael J. Celestine, Supreet Khanal, Alexis Huddleston, Colin Simms, Jessa Faye Arca, Amlan Mitra, Loree Heller, Piotr J. Kraj, Michel Ledizet, John F. Anderson, Girish Neelakanta, Alvin A. Holder, Hameeda Sultana

PII: S0304-4165(17)30325-2

DOI: doi:10.1016/j.bbagen.2017.10.004

Reference: BBAGEN 28958

To appear in:

Received date: 30 March 2017

Revised date: 1 September 2017

Accepted date: 6 October 2017

Please cite this article as: Shovan Dutta, Michael J. Celestine, Supreet Khanal, Alexis Huddleston, Colin Simms, Jessa Faye Arca, Amlan Mitra, Loree Heller, Piotr J. Kraj, Michel Ledizet, John F. Anderson, Girish Neelakanta, Alvin A. Holder, Hameeda Sultana , Coordination of different complexes to copper(II) and cobalt(III) metal centers enhances Zika virus and dengue virus loads in both arthropod cells and human keratinocytes. The address for the corresponding author was captured as affiliation for all authors. Please check if appropriate. Bbagen(2017), doi:10.1016/j.bbagen.2017.10.004

This is a PDF file of an unedited manuscript that has been accepted for publication. As a service to our customers we are providing this early version of the manuscript. The manuscript will undergo copyediting, typesetting, and review of the resulting proof before it is published in its final form. Please note that during the production process errors may be discovered which could affect the content, and all legal disclaimers that apply to the journal pertain. 


\section{Coordination of different complexes to copper(II) and cobalt(III) metal centers enhances Zika virus and dengue virus loads in both arthropod cells and human keratinocytes}

Shovan Dutta ${ }^{1}$, Michael J. Celestine ${ }^{2}$, Supreet Khanal ${ }^{1}$, Alexis Huddleston ${ }^{2, \#}$, Colin Simms ${ }^{1}$, Jessa Faye Arca ${ }^{2, \#}$, Amlan Mitra ${ }^{2, \#}$, Loree Heller ${ }^{3,4}$, Piotr J. Kraj ${ }^{1,5}$, Michel Ledizet ${ }^{6}$, John F. Anderson $^{7}$, Girish Neelakanta ${ }^{1,5}$, Alvin A. Holder ${ }^{2}$, Hameeda Sultana ${ }^{1,5, *}$

${ }^{1}$ Department of Biological Sciences, ${ }^{2}$ Department of Chemistry and Biochemistry, ${ }^{3}$ Frank Reidy Research Center for Bioelectrics, ${ }^{4}$ School of Medical Diagnostic \& translational Sciences College of Health Sciences, ${ }^{5}$ Center for Molecular Medicine, Old Dominion University, Norfolk, VA, USA, ${ }^{6}$ L2 Diagnostics LLC, ${ }^{7}$ The Connecticut Agricultural Experiment Station, New Haven, CT, USA. * Present Address: Department of Chemistry and Biochemistry, University of Southern Mississippi, Hattiesburg, MS, USA

Running title: copper(II) and cobalt(III) containing compounds promote Zika virus and dengue virus infections

\footnotetext{
"Corresponding author: Center for Molecular Medicine, Department of Biological Sciences, Old Dominion University, Norfolk, VA 23529, USA, Email: hsultana@ odu.edu, Phone: +1-
} (757) 683-3402. 


\section{ABSTRACT}

Trace elements such as copper and cobalt have been associated with virus-host interactions. However, studies to show the effect of conjugation of copper(II) or cobalt(III) metal centers to thiosemicarbazone ligand(s) derived from either food additives or mosquito repellent such as 2-acetylethiazole or citral, respectively, on Zika virus (ZIKV) or dengue virus (serotype 2; DENV2) infections have not been explored. In this study, we show that four compounds comprising of thiosemicarbazone ligand derived from 2-acetylethiazole viz., (E)-N-ethyl-2-[1(thiazol-2-yl)ethylidene]hydrazinecarbothioamide (acetylethTSC) (compound 1), a copper(II) complex with acetylethTSC as a ligand (compound 2), a thiosemicarbazone ligand-derived from citral (compound 3) and a cobalt(III) complex with a citral-thiosemicarbazone ligand(compound 4) increased DENV2 and ZIKV replication in both mosquito C6/36 cells and human keratinocytes (HaCaT cells). Treatment of both cell lines with compounds 2 or $\mathbf{4}$ showed increased dengue viral titers at all three tested doses. Enhanced dengue viral plaque formation was also noted at the tested dose of $100 \mu \mathrm{M}$, suggesting higher production of infectious viral particles. Treatment with the compounds $\mathbf{2}$ or $\mathbf{4}$ enhanced ZIKV and DENV2 RNA levels in HeLa cell line and primary cultures of mouse bone marrow derived dendritic cells. Also, pre- or post treatments with conjugated compound $\mathbf{2}$ or $\mathbf{4}$ showed higher loads of ZIKV or DENV2 envelope (E) protein in HaCaT cells. No changes in loads of E-protein were found in ZIKVinfected C6/36 cells, when compounds were treated after infection. In addition, we tested bis(1,10-phenanthroline)copper(II) chloride $\left(\left[\mathrm{Cu}(\text { phen })_{2}\right] \mathrm{Cl}_{2}\right.$, (compound 5) and tris $(1,10$ phenanthroline) cobalt(III) chloride $\left(\left[\mathrm{Co}(\text { phen })_{3}\right] \mathrm{Cl}_{3}\right.$, (compound 6) that also showed enhanced DENV2 loads. Also, we found that copper(II) chloride dehydrate $\left(\mathrm{CuCl}_{2} \cdot 2 \mathrm{H}_{2} \mathrm{O}\right)$ or cobalt(II) 
chloride hexahydrate $\left(\mathrm{CoCl}_{2} \bullet 6 \mathrm{H}_{2} \mathrm{O}\right)$ alone had no effects as "free" cations. Taken together, these findings suggest that use of $\mathrm{Cu}(\mathrm{II})$ or $\mathrm{Co}(\mathrm{III})$ conjugation to organic compounds, in insect repellents and/or food additives could enhance DENV2/ZIKV loads in human cells and perhaps induce pathogenesis in infected individuals or individuals pre-exposed to such conjugated complexes. 
KEY WORDS: Zika virus, dengue virus, viral replication, copper(II) and cobalt(III),

thiosemicarbazones, 1, 10-phenanthroline 


\section{IMPORTANCE}

Mosquito-borne diseases are of great concern to the mankind. Use of chemicals/repellents against mosquito bites and transmission of microbes has been the topic of interest from many years. Here, we show that thiosemicarbazone ligand(s) derived from 2-acetylethiazole or citral or 1,10-phenanthroline upon conjugation with copper(II) or cobalt(III) metal centers enhances dengue virus (serotype 2; DENV2) and/or Zika virus (ZIKV) infections in mosquito, mouse and human cells. Enhanced ZIKV/DENV2 capsid mRNA or envelope protein loads were evident in mosquito cells and human keratinocytes, when pre-treated with compounds before/after infections. Also, treatment with copper(II) or cobalt(III) conjugated compounds increased viral titers and number of plaque formations. These studies suggest that conjugation of compounds in repellents/essential oils/natural products/food additives with copper(II) or cobalt(III) metal centers may not be safe, especially in tropical and subtropical places, where several dengue infection cases and deaths are reported annually or in places with increased ZIKV caused microcephaly. 


\section{INTRODUCTION}

Insect bites, food or crop damage and transmission of pathogens to humans, animals and plants has led to the extensive use of insecticides, pesticides and insect attractants or repellents $[1,2]$. Use of these substances has substantially been increased in military personnel and in agriculture or horticulture practices. Over a decade, several of these chemicals have been used extensively in all parts of the world. Some synthetic compounds or chemicals are of major concern to the environment and human health and they have been withdrawn due to the adverse effects and serious human health hazards [3-8]. One of the most recent study tested that several of the repellents including citronella candles had no effects and did not reduced mosquito attraction to humans [9]. The disadvantages of some insecticides have promoted the use of plant-based essential oils and their derived natural products, belonging to several herb species that poses repellent activities $[7,10]$. Some of the essential oils, herbal skin products and nonnatural inorganic insecticides (the contact insecticides that are toxic to insects upon direct contact) have been shown to contain metals such as arsenates, copper, cobalt and fluorine compounds in small amounts and sulfur as a major component [11]. Also, both copper sulfate and cobalt chloride has been shown to improve the varieties in rice and vegetables that are mostly consumed in Australia and some parts of Asia [12]. In addition, complex mixtures of volatile organic compounds produced from plant-based essential oils or natural products such as citral have been extensively used as repellents to prevent transmission of human pathogens through biting arthropods such as mosquitoes [7,10,13]. 
Mosquitoes are the primary vectors responsible for the transmission of arthropod-borne flaviviruses that cause microcephaly (Zika Virus), dengue hemorrhagic fever, yellow fever, West Nile neuroinvasive disease (WNND) and Japanese encephalitis. With regard to the global impact from arthropod-borne diseases, dengue is the most important human pathogen (that exist as four serotypes; DENV-1, 2, 3 and 4) that should be addressed promptly. According to the $2009 \mathrm{WHO}$ criteria, dengue cases have been classified according to the levels of severity. Dengue infections without warning signs or with warning signs (such as abdominal pain, persistent vomiting, fluid accumulation, mucosal bleeding, liver enlargement, increasing hematocrit with decreased platelet numbers and lethargy) were considered as less severe. However, dengue infections with severe plasma leakage, bleeding or organ failures were considered as severe cases $[14,15]$. Approximately 20,000-25,000 deaths and 50-100 million dengue infections with 500,000 hospitalizations are reported, annually [16]. Also, there are no fully effective vaccines available for human use and prevention of dengue $[17,18]$. Nevertheless, recently, WHO immunization group (Strategic Advisory Group of Experts; SAGE) has recommended the use of partially effective dengue vaccine (a live attenuated tetravalent dengue vaccine developed by Sanofi Pasteur; CYD-TDV, named Dengvaxia) that has been licensed and used in 11 countries including Brazil, Mexico, Singapore, Thailand and Indonesia [19]. Related to dengue, Zika virus (ZIKV) is an emerging infectious agent transmitted and spread by the daytime active Aedes mosquitoes, such as A. aegypti and A. albopictus. ZIKV can be transmitted by blood transfusions, sexual and placental leakage from the mother to the fetus [20,21]. An important public health concern has been declared due to global epidemic of ZIKV infections. The association between ZIKV infection during pregnancy and intrauterine fetal infection, microcephaly, brain damage, congenital malformation syndrome and evidences from laboratory 
models of fetal infections are reported [20-22]. The best prevention practice is the use of mosquito nets, protective clothing such as long-sleeve shirts and full pants and insect repellents to avoid the mosquito bites. In high endemic areas, it becomes important to use repellents on a routine basis to prevent bites from infected mosquitoes.

Several reports suggest that trace elements such as copper and cobalt play an important role in the host immunomodulatory activities during viral infections [23,24]. Any changes in the levels of trace elements could impact disease severity [25]. Essential oils from plants and herbs can inactivate enveloped and non-enveloped viral replication and exhibit antiviral activities [2629]. Due to the strong antiviral and antimicrobial activities, novel citral-based compounds (the well-known natural insect repellent) are developed continuously [26-29]. Studies that show the effect of conjugation of citral-based compounds with different trace elements on ZIKV and dengue virus replication has not been explored. The purpose of the current study is to analyze the effects of copper(II) and cobalt(III) metal conjugations with organic compounds (that are used in repellents or food additives) on DENV2/ZIKV infections. The four compounds analyzed in this study are selected based on the structural activity relationship (SAR) in order to determine the best efficacy in inhibition of the virus. It has been reported that when "free" thiosemicarbazone ligands are coordinated to a metal center, the efficacy in the activity is enhanced in comparison to the "free" ligands. In this study, we show that treatment of mosquito (C6/36 cells) and human keratinocytes (HaCaT cells), HeLa cells and primary cultures of mouse bone marrow derived dendritic cells with thiosemicarbazones coordinated to $\mathrm{Cu}$ (II) or $\mathrm{Co}$ (III) metal centers enhances ZIKV and DENV2 infections. Our data suggests that use of coordinated 
version with metal centers in the repellent formulations may aid better replication of ZIKV and DENV2 in the human cells upon transmission by the biting mosquitoes. 


\section{MATERIALS AND METHODS}

Synthesis of the ligands and the compounds. Analytical or reagent grade chemicals were used throughout this study. All the chemicals including solvents were obtained from Sigma-Aldrich (St. Louis, MO, U.S.A.) or other commercial vendors, and used as received. Microanalyses (C, H, N) were performed by Intertek Chemical and Pharmaceuticals, 291 Route 22 East, Salem Industrial Park, Building \#5, Whitehouse, NJ 08888, U.S.A. The FT IR (Fourier Transform infrared) spectrum was acquired in the range of $4000-400 \mathrm{~cm}^{-1}$ using the Attenuated Total Reflectance (ATR) accessory (with a diamond crystal) on a Nicolet 6700 FT IR spectrometer. ${ }^{1} \mathrm{H}$ nuclear magnetic resonance ( ${ }^{1} \mathrm{H}$ NMR) spectra were acquired on a Bruker AVANCE III 400 MHz spectrometer with deuterated dimethyl sulfoxide- $\mathrm{d}_{6}\left(\right.$ DMSO- $\left._{6}\right)$ as solvent. All ${ }^{1} \mathrm{H}$ NMR spectra were processed with the Spectrus Processor 2012 software, which is available from Advanced Chemistry Development (ACD, Inc., 8 King Street East, Suite 107, Toronto, Ontario M5C 1B5, Canada).

\section{The "free" salts and complexes.}

The "free" $\mathrm{CuCl}_{2} \cdot 2 \mathrm{H}_{2} \mathrm{O}$ and $\mathrm{CoCl}_{2} \cdot 6 \mathrm{H}_{2} \mathrm{O}$ salts were obtained from Sigma-Aldrich Corporation.

Synthesis of (E)-N-ethyl-2-[1-(thiazol-2-yl)ethylidene]hydrazinecarbothioamide (acetylethTSC) 1 and [Cu(acetylethTSC) Cl]Cl $0.25 \mathrm{C}_{2} \mathrm{H}_{5} \mathrm{OH} 2$ (Compounds 1 and 2, respectively)

(E)-N-ethyl-2-[1-(thiazol-2-yl)ethylidene]hydrazinecarbothioamide $\quad$ (acetylethTSC) $\mathbf{1}$ was synthesized and characterized as by Lewis et al.; [30] while the complex, $\left[\mathrm{Cu}(\right.$ acetylethTSC) $\mathrm{Cl}] \mathrm{Cl} \bullet 0.25 \mathrm{C}_{2} \mathrm{H}_{5} \mathrm{OH} 2$ (where acetylethTSC $=(E)$ - $N$-ethyl-2-[1-(thiazol-2- 
yl)ethylidene]hydrazinecarbothioamide) was synthesized and characterized as by Sandhaus et al. [31].

Synthesis of citralEtTSC $\bullet 0.25 \mathrm{C}_{2} \mathrm{H}_{5} \mathrm{OH} 3$ (Compound $\mathbf{3}$ )

Citral (3.0 g, $3.377 \mathrm{ml}, 20 \mathrm{mmol})$ and 4-ethyl-3-thiocarbazide $(2.4 \mathrm{~g}, 20 \mathrm{mmol})$ were mixed in a $250 \mathrm{ml}$ round bottom flask, followed by anhydrous ethanol $(100 \mathrm{ml})$ and five drops of glacial acetic acid. The reaction mixture was refluxed with stirring for three hours and evaporated to dryness. The resulting oil was allowed to stay at room temperature until it solidified to leave the resulting product. Yield $=4.8 \mathrm{~g}(91 \%)$. Calc. $\mathrm{C}_{13.5} \mathrm{H}_{24.5} \mathrm{~N}_{3} \mathrm{O}_{0.25} \mathrm{~S}, \mathrm{C}, 61.21 ; \mathrm{H}, 9.32 ; \mathrm{N}, 15.86 \%$. Found: C, 60.82; H, 9.34; N, 15.76\%. FT IR (v/cm $\left.{ }^{-1}\right): 3164(\mathrm{~m})\left(-\mathrm{N}^{1} \mathrm{H}\right), 3054(\mathrm{~m})\left(-\mathrm{N}^{2} \mathrm{H}\right), 1059$ (m) $(\mathrm{N}-\mathrm{N}), 1543(\mathrm{~m})(\mathrm{TSC}(\mathrm{C}=\mathrm{N})),(1296)(\mathrm{m})$ and $(813)(\mathrm{m})(\mathrm{C}=\mathrm{S}) .{ }^{1} \mathrm{H}$ NMR $(400 \mathrm{MHz}$; DMSO-d $\left.)_{6}\right) ; \delta_{\mathrm{H}}=1.16\left(\mathrm{t}, J^{t}=7.10 \mathrm{~Hz}, 3 \mathrm{H},-\mathrm{CH}_{3}\right), 2.42\left(\mathrm{~s}, 3 \mathrm{H}, \mathrm{CH}_{3} \mathrm{CH}=\mathrm{N}\right), 3.61\left(\mathrm{~d}, 2 \mathrm{H}, \mathrm{CH}_{2}\right)$, $7.79\left(\mathrm{~d}, J^{d}=3.21 \mathrm{~Hz}, \mathrm{CH}_{\mathrm{ar}}\right), 7.88\left(\mathrm{~d}, J^{d}=3.19 \mathrm{~Hz}, \mathrm{CH}_{\mathrm{ar}}\right), 8.08\left(\mathrm{~d}, J^{d}=3.24 \mathrm{~Hz}, \mathrm{CH}_{\mathrm{ar}}\right), 8.30(\mathrm{~s}, \mathrm{H}$, aminic NH), 10.58 (s, 1H, hydrazinic-NH), and 13.2 (s, H-bonded hydrazinic-NH) ppm.

Synthesis of $\left[\mathrm{Co}(\text { phen })_{2}\left(\right.\right.$ citralEtTSC)] $\left(\mathrm{NO}_{3}\right)_{3} \bullet 0.25 \mathrm{H}_{2} \mathrm{O} \bullet 1.5 \mathrm{C}_{2} \mathrm{H}_{5} \mathrm{OH} 4$ (Compound 4)

At first, $\left.[\mathrm{Co} \text { (phen) })_{2} \mathrm{CO}_{3}\right] \mathrm{Cl} \cdot 5 \mathrm{H}_{2} \mathrm{O}$ was synthesized using the procedure as reported by Kashiwabara et al. [32]. First, we prepared $\left[\mathrm{Co}(\mathrm{phen})_{2}\left(\mathrm{H}_{2} \mathrm{O}\right)_{2}\right]\left(\mathrm{NO}_{3}\right)_{3}$, then $\left[\mathrm{Co}(\text { phen })_{2}\left(\mathrm{H}_{2} \mathrm{O}\right)_{2}\right]\left(\mathrm{NO}_{3}\right)_{3} \bullet 2 \mathrm{H}_{2} \mathrm{O}$ was synthesized by the acid hydrolysis of $\left[\mathrm{Co}(\text { phen })_{2} \mathrm{CO}_{3}\right] \mathrm{Cl} \bullet 5 \mathrm{H}_{2} \mathrm{O}$ using the synthesis as reported by $\mathrm{Ye}$ et al. [33]. Finally, $\left[\mathrm{Co}(\text { phen })_{2}\left(\mathrm{H}_{2} \mathrm{O}\right)_{2}\right]\left(\mathrm{NO}_{3}\right)_{3} \bullet 2 \mathrm{H}_{2} \mathrm{O}$ was placed in an oven set at $110{ }^{\circ} \mathrm{C}$ for 24 hours in order to produce anhydrous $\left[\mathrm{Co}(\text { phen })_{2}\left(\mathrm{H}_{2} \mathrm{O}\right)_{2}\right]\left(\mathrm{NO}_{3}\right)_{3}$. $\left[\mathrm{Co}(\text { phen })_{2}\left(\mathrm{H}_{2} \mathrm{O}\right)_{2}\right]\left(\mathrm{NO}_{3}\right)_{3}(0.80 \mathrm{~g}, 1.2 \mathrm{mmol})$ and citralEtTSC $\bullet 0.25 \mathrm{C}_{2} \mathrm{H}_{5} \mathrm{OH}(0.32 \mathrm{~g}, 1.2 \mathrm{mmol})$ in anhydrous ethanol $(410 \mathrm{ml})$ were refluxed in a $500 \mathrm{ml}$ round bottom flask with stirring at $110{ }^{\circ} \mathrm{C}$ under argon for 24 hours. The mixture was rotary evaporated to dryness. The solid was washed with ether and collected. Yield $=1.0(91 \%)$. 
Calc. $\mathrm{C}_{40} \mathrm{H}_{48.5} \mathrm{CoN}_{10} \mathrm{O}_{10.75} \mathrm{~S}, \mathrm{C}, 51.53 ; \mathrm{H}, 5.24 ; \mathrm{N}, 15.02 \%$. Found: C, 51.53; H, 4.57; N, $14.57 \%$. Complexes 5 and $6,\left[\mathrm{Cu}(\text { phen })_{2}\right] \mathrm{Cl}_{2}$ and $\left[\mathrm{Co}(\text { phen })_{3}\right] \mathrm{Cl}_{3}$ were synthesized respectively as by the literature procedure $[34,35]$.

All tested compounds were completely solubilized in DMSO and were prepared as $1 \mathrm{ml}$ of $100 \mathrm{mM}$ solutions (compounds $\mathbf{1 ,} \mathbf{3}$ and $\mathbf{4}$ ) or $20 \mathrm{mM}$ stocks of compound $\mathbf{2}$ (due to low solubility issues) or $0.1 \mathrm{mM}$ stock of Compound 5 and $\mathbf{6}$ were prepared. The indicated doses 1 , 10 and $100 \mu \mathrm{M}$ were prepared from the stock solutions and used as test doses throughout the study. The compound stocks and dilutions were kept as recommended by the previous studies.

Cell Culture and Infection. Mosquito (C6/36) cells and Vero (African Green Monkey kidney) cell line were purchased from American Type Culture Collection (ATCC). Human keratinocytes (HaCaT cells) were obtained from Dr. Loree Heller, Center for Bioelectrics. C6/36 or HaCaT cells were plated in a 24/12 well plate at a density of $1 \times 10^{5}$ cells per well in complete MEM or DMEM medium containing 10\% FBS, L-glutamine and Pen/Strep and kept at either $30^{\circ} \mathrm{C}$ or 37 ${ }^{\circ} \mathrm{C}$ with $5 \% \mathrm{CO} 2$, respectively. Cells were either treated with respective compounds $\mathbf{1}, \mathbf{2}, \mathbf{3}$ or 4 (with indicated doses; 1,10 or $100 \mu \mathrm{M}$ ) for 24 hours before or after infection with ZIKV/DENV2 (multiplicity of infection, MOI = 1) for 24-hour. Compounds 5 and $\mathbf{6}$ or the "free" $\mathrm{Cu}(\mathrm{II})$ and $\mathrm{Co}(\mathrm{III})$ salts (with indicated doses; 1,10 or $100 \mu \mathrm{M}$ ) were also treated for 24 hours followed by infection with DENV2 (multiplicity of infection, MOI = 1) for another 24hour. ZIKV strain, VR-1838, was obtained from ATCC or DENV2 (Serotype 2); El Salvador TVP2176 strain was obtained from Dr. John F. Anderson, Connecticut Agricultural Experiment Station. DMSO-treated or untreated (uninfected or infected) cells served as controls. 
RNA extraction, cDNA synthesis and Quantitative Real-time PCR (Q-PCR) Analysis. Total RNA from $\left(1 \times 10^{5}\right)$ of either C6/36 cells or HaCaT cells, first treated with the compounds (for 24 hours) using different doses $(1,10$ or $100 \mu \mathrm{M})$ followed by infection with DENV2/ ZIKV (MOI 1; 24 hour post infection) or post-treated (24 hours) with respective compounds (indicated doses) after DENV2/ZIKV infection (MOI 1; 24 hours) were generated using Aurum Total RNA Mini kit (BioRad, Hercules, CA) following manufacturer instructions. RNA was converted to cDNA using iScript cDNA synthesis kit (BioRad). The generated cDNA was used as template for the amplification of DENV2/ZIKV; capsid/NS5 transcripts, respectively, from cDNA with primers as described [36,37]. As an internal control and to normalize the amount of template, either mosquito or mouse or human beta actin amplicons were quantified using published primers [36]. Q-PCR data showing DENV2/ZIKV loads were presented by normalizing expression of capsid/ NS5 gene transcripts to either mosquito or mouse or human beta actin. QPCR was performed using iQ-SYBR Green Supermix and CFX96 touch System (BioRad). Standard curves were prepared using 10 -fold serial dilutions starting from 1 to $0.00001 \mathrm{ng} / \mu 1$ of known quantities of DENV2/ ZIKV, capsid/ NS5, and respective beta-actin fragments. Following are the oligonucleotides used in this study: DENV2 capsid, 5,

AATATGCTGAAACGCGAGAGAAACCGCG 3' and 5' CTCTTCAGTATCCCTGCTGTTGG 3'; ZIKV NS5, 5' AARTACACATACCARAACAAAGTGGT 3' and 5'

TCCRCTCCCYCTYTGGTCTTG 3'; human actin, 5' AGCCTCGCCTTTGCCGA 3' and 5' CTGGTGCCTGGGGCG 3'; mouse actin, 5' CCCTAGGCACCAGGGTGTGA 3' and 5' GGGGTGTTGAAGGTCTCAAACA 3'; mosquito actin, 5' CCATGTACGTCGCCATCCA 3' and 5' GCGGTGGCCATTTCCTG 3'; human IFN-beta, 5' CAGCAATTTTCAGTGTCAGAAGCT 3' and 5' TCATCCTGTCCTTGAGGCAGT 3'; and 
human TNF-alpha, 5' CCCAGGCAGTCAGATCATCTT 3' and 5'

TCTCAGCTCCACGCCATT 3'.

Western Blotting. Total proteins from 1 x $10^{5}$ of either C6/36 cells or HaCaT cells infected with DENV2 (MOI 1; 24 hour post infection) or with ZIKV (MOI 1 or 5; for 24 hour) and then followed by treatments with respective compounds at different doses $(1,10,100 \mu \mathrm{M})$ for another 24-hour period or vice versa (treated with compounds and then infected; in a similar manner as described above) were collected in ice-cold modified RIPA buffer (G-Biosciences, BioExpress, Kaysville, UT). Total proteins were estimated using BCA kit (Pierce, ThermoScientific). Total lysates from $\mathrm{C} 6 / 36$ or $\mathrm{HaCaT}$ cells $(25 \mu \mathrm{g})$ were separated on $4-20 \%$ gradient or $12 \%$ SDSPAGE gels (NuSep; BioExpress). Following gel electrophoresis, blotting (on nitrocellulose membranes) and blocking (5\% milk buffer or BSA NAP-blocker solution; G-Biosciences, BioExpress) was processed and blots were incubated with 4G2 primary antibody (non-reducing conditions), obtained from Dr. Michel Ledizet, L2 Diagnostics, Inc. Monoclonal Anti-Flavivirus Group Antigen, Clone D1-4G2-4-15 (Catalog Number; NR-50327), antibody obtained from BEI resources was used to detect ZIKV E-protein. Mouse monoclonal IgG conjugated with HRP (Santa Cruz Biotechnologies, Dallas, TX) were used as secondary antibodies for detection. Total protein profiles serve as loading controls and not for comparison between the compounds. The differences in protein profile gels are due to use of either stain-free gels images after run, or staining of gels with either colloidal Coomassie blue or R-250 Coomassiee blue solutions. ECL detection of antibody binding was performed with WesternBright ECL kit (Advansta, BioExpress). Blots were scanned using Chemidoc MP imaging system and recommended Image Lab software from the manufacturer (BioRad). 
Virus Titration Assays. For the titration assay, briefly, C6/36 or HaCaT cells were seeded into 96 well plates and at a density of $1 \times 10^{5}$ cells/well in $225 \mu 1$ of either MEM or DMEM complete medium with 10\% FBS, pen/Strep and L-Glutamine. Cells were incubated overnight at either 30 ${ }^{\circ} \mathrm{C}$ or $37^{\circ} \mathrm{C}$ with $5 \% \mathrm{CO} 2$, respectively. Cells were treated with respective compounds $\mathbf{1 - 4}$ at doses of 1,10 or $100 \mu \mathrm{M}$ (for 24 hours), followed by infection with DENV2 (MOI 1) for another 24 hours. Each of the compound and respective doses were kept as six independent replicates in addition to the uninfected, infected and infected-DMSO treated controls. Following 24 hour postinfection, cells were fixed with acetone-PBS mixture (3:1) for $20 \mathrm{~min}$ at $-20^{\circ} \mathrm{C}$. Immediately after fixation, plates were air dried and washed with 1 x PBS and blocked with 5\% FBS-PBS0.05\% Sodium Azide for 15 min at RT. After blocking, cells were incubated with 4G2monoclonal antibody for overnight at $4^{\circ} \mathrm{C}$. Cells were washed three times with PBS and incubated with Alexa-594 labeled mouse secondary antibody for 1 hour at RT, followed by washes (3X) with PBS. Plates were analyzed using EVOS fluorescence system (Invitrogen/Thermoscientific) and cells were scored for fluorescence or the presence or absence of infection in comparison to the positive (Infected and infected-DMSO-treated) or negative (uninfected) controls. Percentages were calculated from ratio of fluorescent cells and no fluorescent cells and as manual countings from eight microscopic fields. We collected eight images for each treatment and respective doses and representative images are shown in Supplementary information. Infection indicated by red fluorescence was determined as average from collected images and percentages were plotted in comparison to the infected-DMSO-treated controls. 
Viral Plaque Formation Assay. Plaque assays were performed as described [36]. For the plaque formation assay, briefly, Vero cells were seeded into 6 well plates and at a density of $1.5 \times 10^{6}$ cells/well in DMEM complete medium with $10 \%$ FBS. Cells were incubated overnight at $37^{\circ} \mathrm{C}$ with 5\% CO2 and then treated with compounds $\mathbf{1 - 4}$ at doses of $100 \mu \mathrm{M}$ (for 24 hours), followed by infection with DENV2 (MOI 1) for 2 hours. Following post-infection, medium was removed and warm 2\% Seaplaque agarose (Lonza) overlay with complete DMEM media (1:1 ratio) containing antibiotic and antimycotics solution (1\% each; Sigma) was added. Plates were incubated for additional 5 days, at $37{ }^{\circ} \mathrm{C}$ and $5 \% \mathrm{CO} 2$. After an incubation period, plaques were stained with $0.03 \%$ of Neutral Red (Sigma) for 4 hours; stain was removed to count plaques. Each of the compounds (at the dose of $100 \mu \mathrm{M}$ ) was kept as two independent replicates in addition to the controls (infected and infected-DMSO treated). Representative images are shown for each compound and controls. Plaques counting are averages from three independent readouts.

Isolation and culturing of mouse bone marrow-derived dendritic Cells. Bone marrow cells were isolated from femurs and tibias of C57BL/6 mice, and red blood cells were lysed with ammonium chloride. Remaining cells were plated at a density of $7 \times 10^{6}$ per $100-\mathrm{mm}$ cell culture dish in 10ml of $\alpha$-MEM media (HyClone) supplemented with 10\% Fetal Bovine Serum (Atlanta Biologicals), $2 \mathrm{mM} \mathrm{L-glutamine,} \mathrm{dextrose,} \mathrm{essential} \mathrm{and} \mathrm{non-essential} \mathrm{amino} \mathrm{acids,}$ sodium pyruvate, sodium bicarbonate, antibiotics, and 2- $\beta$-mercaptoethanol. Granulocytemacrophage colony- stimulating factor (GM-CSF; Peprotech; 5ng/ml) was added at the time of plating, and again after 72 hours of incubation. Experiments using animals were in accordance with protocols from the Institutional Animal Care and Usage Committee (as per the approved protocol 14-009). For infection and treatment with compounds, we re-plated dendritic cells into 
24 well plates as $1 \times 10^{5}$ cells/ml in each well and infected with either DENV2/ZIKV $(\mathrm{MOI}=1)$, respectively. After $24 \mathrm{~h}$ post infection, dendritic cells were treated with all four compounds at different doses $(1,10,100 \mu \mathrm{M})$ for another 24 hour, and collected for RNA extractions.

Statistics. Statistical significance of differences observed in data sets was analyzed using Prism6 software (GraphPad, La Jolla, CA) and Microsoft Excel. For data to compare two means, the non-paired, two-tail Student $t$ test was performed for all analysis. P values of $<0.05$ were considered significant in all tests, error bars represent mean (+SD) values. Statistical test and P values are shown. 


\section{RESULTS}

Synthesis and Schemes of compounds. (E)- $N$-ethyl-2-[1-(thiazol-2-yl)

ethylidene]hydrazinecarbothioamide (acetylethTSC) compound $\mathbf{1}$ was synthesized as described by Lewis et al.; [30] while the compound $2,\left[\mathrm{Cu}\right.$ (acetylethTSC)Cl]Cl $\bullet 0.25 \mathrm{C}_{2} \mathrm{H}_{5} \mathrm{OH} 2$ (where acetylethTSC $=(E)$ - $N$-ethyl-2-[1-(thiazol-2-yl)ethylidene]hydrazinecarbothioamide) was synthesized as described by Sandhaus et al. [31] (Scheme 1, Supplementary Information). Compounds 3 and $\mathbf{4}$ were synthesized as described in (Scheme 2, Supplementary Information). The ${ }^{1} \mathrm{H}$ NMR spectrum of compound $\mathbf{3}$ (citralEtTSC $\bullet 0.25 \mathrm{C}_{2} \mathrm{H}_{5} \mathrm{OH}$ ) is shown in Supplementary Fig. 1A. The thiosemicarbazone ligand derived from 2-acetylethiazole (compound 1), 2acetylthiazole thiosemicarbazone ligand-copper(II) complex (compound 2), had been synthesized in [31]. Compounds $\mathbf{3}$ and $\mathbf{4}$ that are thiosemicarbazone ligands derived from citral without (compound 2) or with Co(III) complex (compound 4), respectively, were synthesized in this study as shown in schemes 1 and 2. Complexes 5 and $\mathbf{6},\left[\mathrm{Cu}(\text { phen })_{2}\right] \mathrm{Cl}_{2}$ and $\left[\mathrm{Co}(\mathrm{phen})_{3}\right] \mathrm{Cl}_{3}$, respectively, were synthesized in this study as by the literature procedure [34,35]. Schemes 3 and 4 in Supplementary information show the synthesis of complexes 5 and $\mathbf{6}$. The ${ }^{1} \mathrm{H}$ NMR spectrum of complexes 5 and $\mathbf{6}$ and $\left[\mathrm{Co}(\mathrm{phen})_{3}\right] \mathrm{Cl}_{3}$ are shown in Supplementary Fig. 1B and 1C. The methods used to synthesize these compounds are validated and are routinely been used in the biochemistry laboratory [31].

\section{Thiosemicarbazone and 1, 10-Phenanthroline ligands conjugated with $\mathrm{Cu}$ (II) or $\mathrm{Co}$ (III)} complexes enhance dengue virus loads. We determined the dengue virus loads in order to investigate any interference of these compounds in virus inhibition. C6/36 cells or $\mathrm{HaCaT}$ cells 
were infected with DENV2 (MOI = 1) for 24 hours, followed by 24-hour of incubations with respective compounds at different doses of 1,10 and $100 \mu \mathrm{M}$ concentrations. Q-PCR data showed that treatment of C6/36 cells with compounds 1 and $\mathbf{3}(100 \mu \mathrm{M})$ and compounds 2 and 4 $(10$ and $100 \mu \mathrm{M})$ concentrations significantly $(\mathrm{P}<0.05)$ enhanced the DENV2 capsid mRNA transcripts in comparison to the infected-DMSO control (Fig. 1A). Immunoblotting analysis showed increased dengue envelope (E) protein loads in C6/36 cells treated with compound 2 or 4 at all concentrations $(1,10$ and $100 \mu \mathrm{M})$ in comparison to DMSO-treated control (Fig. 1B). Human keratinocytes treated with compounds $\mathbf{2}$ and $\mathbf{4}(10$ and $100 \mu \mathrm{M})$ also showed significant $(\mathrm{P}<0.05)$ increase in dengue capsid mRNA transcripts in comparison to the infected-DMSOtreated control (Fig. 1C). However, compound $\mathbf{1}$ showed significantly increased dengue capsid mRNA transcripts at $100 \mu \mathrm{M}$ treatment (Fig. 1C). Immunoblotting analysis with HaCaT cells revealed that compounds 2 and 4 (at 10 and $100 \mu \mathrm{M}$ ) showed dramatic increase in dengue Eprotein levels in comparison to the infected-DMSO treated control (Fig. 1D). Increased dengue virus E-protein loads were evident in compound 1-treated cells even at $100 \mu \mathrm{M}$ concentrations in comparison to DMSO-treated controls. Total protein profiles serve as loading control and are not shown for comparison to the infected (untreated) or infected-DMSO treated samples (Fig. 1B \& 1D). In addition to compounds $\mathbf{2}$ and $\mathbf{4}$, we tested complexes $\mathbf{5}$ and $\mathbf{6}$ to find if coordination of copper(II) or cobalt(III) to these 1, 10-phenanthroline compounds also enhances DENV2 loads upon treatment. We found that in both mosquito and HaCaT cells, complexes $\mathbf{5}$ and $\mathbf{6}$ also enhanced DENV2 loads upon 24-hour treatment followed by 24 hour post-infection (Supplementary Fig. 2A and 2B). Viral loads were enhanced in a dose dependent manner when complexes 5 and $\mathbf{6}$ were treated at increasing concentrations of 1, 10, $100 \mu \mathrm{M}$ (Supplementary Fig. 2A and 2B). In order to include the possibility that the inorganic salts containing $\mathrm{Cu}(\mathrm{II})$ or 
$\mathrm{Co}$ (III) may itself enhance the DENV2 loads, we tested the $\mathrm{CuCl}_{2} \cdot 2 \mathrm{H}_{2} \mathrm{O}$ and $\mathrm{CoCl}_{2} \cdot 6 \mathrm{H}_{2} \mathrm{O}$ salts independently in both mosquito and $\mathrm{HaCaT}$ cells. We found that in both cell lines the salts alone did not enhanced the DENV2 loads at the similar treatments (with tested doses of 1, 10, $100 \mu \mathrm{M}$ ) and infection times (Supplementary Fig. 2C and 2D). This data suggested that $\mathrm{Cu}(\mathrm{II})$ or $\mathrm{Co}(\mathrm{III})$ salts alone has no effects as free cations.

\section{$\mathrm{Cu}(\mathrm{II})$ or $\mathrm{Co}(\mathrm{III})$ metal centers with thiosemicarbazone ligands enhance production of} infectious viral particles. To further confirm the enhanced viral replication and increased DENV2 loads upon treatment with compounds ( 2 and $\mathbf{4}$ ), we performed the virus titration and plaque formation assays as described in methods. In both mosquito and HaCaT cells, virus titration assay showed percentage of infected cells (determined by fluorescent signals). Both compounds $\mathbf{2}$ and $\mathbf{4}$, showed significantly $(\mathrm{P}<0.05)$ increased percentage of infected cells at all tested doses of 1,10 and $100 \mu \mathrm{M}$, for 24 hours of treatment followed by another 24 hour postinfection period (Fig. 2A and 2B). All four compounds (1-4) at $100 \mu \mathrm{M}$ treatment showed increased production of viral infectious particles in both mosquito and human cells (Fig. 2A and 2B). However, compounds $\mathbf{2 , 3}$ and $\mathbf{4}$ showed increased virus loads even at lower concentration of $10 \mu \mathrm{M}$ in both cells (Fig. 2A and 2B). Representative images are shown for increased number of infected cells with pre-treatment of compounds 1-4 in both mosquito and $\mathrm{HaCaT}$ cells in comparison to their respective infected-DMSO treated controls (Supplementary Figures 3 and 4). The plaque formation assay further confirmed the increased production of viral plaques in Vero cells treated with compounds $\mathbf{1 - 4}$ at $100 \mu \mathrm{M}$ (Fig. 2C and 2D). The plaques formed in the presence of compounds $\mathbf{3}$ and $\mathbf{4}$ were large with bigger diameter in comparison to the plaques formed in infected-DMSO-treated controls (Fig. 2C). Also at $100 \mu \mathrm{M}$ treatments, compound 2 
showed several but smaller plaques in comparison to compound 1. The numbers of plaques formed were significantly increased upon treatment with compounds $\mathbf{2}$ and $\mathbf{4}$ in comparison to the compounds 1 and 3 (Fig. 2D). This data further confirmed that treatment with compounds containing $\mathrm{Cu}(\mathrm{II})$ or $\mathrm{Co}(\mathrm{III})$ metal centers increased production of infectious viral particles. Also, we analyzed the antiviral/cytokine response in DENV2-infected HaCaT cells treated with different compounds. Treatment of HaCaT cells with compound $\mathbf{1}(10 \mu \mathrm{M})$, showed significantly decreased levels of IFN-beta transcripts in comparison to infected-DMSO-treated control (Supplementary Fig. 5A). No differences were evident with the treatment with other compounds. In addition, we noted that treatment of $\mathrm{HaCaT}$ cells with compounds $(\mathbf{1}, \mathbf{2}$ and $\mathbf{4})$ at $1 \mu \mathrm{M}$ concentration showed significantly $(\mathrm{P}<0.05)$ decreased levels of TNF-alpha transcripts (Supplementary Fig. 5B). Due to the observation of increased viral replication upon treatment with compound 4, we determined whether treatment with this compound elicits similar effect in additional human cell lines such as HeLa cells. QPCR analysis revealed that HeLa cells treatment with compound 4 at $100 \mu \mathrm{M}$ showed significantly $(\mathrm{P}<0.05)$ increased DENV2 loads, in comparison to the infected DMSO-controls (Supplementary Fig. 5C).

\section{Thiosemicarbazone ligands conjugated with $\mathrm{Cu}(\mathrm{II})$ or $\mathrm{Co}(\mathrm{III})$ enhance DENV2 and ZIKV} loads in primary cultures of murine bone marrow derived dendritic cells. We next determined DENV2/ZIKV loads in the primary cultures of mouse dendritic cells isolated from bone marrow derived precursor cells. Dendritic cells were infected with either DENV2 or ZIKV $(\mathrm{MOI}=1)$ for 24 hours, and then treated with compounds $\mathbf{1 - 4}$ at different doses $(1,10$ and 100 $\mu \mathrm{M}$ ) for another 24 hours. QPCR analysis showed that both DENV2 (Fig. 3A) capsid transcripts and ZIKV NS5 transcripts (Fig. 3B) were significantly $(\mathrm{P}<0.05)$ increased in $\mathrm{Cu}(\mathrm{II})$ conjugated 
compound 2 (both 10 and $100 \mu \mathrm{M}$ treatments), however, unconjugated compound $\mathbf{1}$ showed significant $(\mathrm{P}<0.05)$ increase in only ZIKV loads. Compound $\mathbf{3}$ treatments (at $100 \mu \mathrm{M}$ ) showed enhanced viral loads in both DENV2 and ZIKV infected dendritic cells (Fig. 3A \& 3B). In dendritic cells infected with DENV2, treatment with compound $\mathbf{4}$ showed a significant $(\mathrm{P}<0.05)$ increase in virus loads. However, treatments with compound $4(100 \mu \mathrm{M})$ showed enhanced DENV2/ZIKV loads in comparison to their respective controls (Fig. 3A \& 3B).

\section{Treatment with copper(II) conjugated compound post infection with ZIKV enhances viral} burden in both mosquito and human cells. In C6/36 cells infected with ZIKV (MOI = 1; for $24 \mathrm{~h}$ ), followed by treatment with compounds 1-4 (at 1,10 and $100 \mu \mathrm{M}$ ) for another 24 hours, we found that ZIKV loads (NS5 mRNA transcripts) were significantly $(\mathrm{P}<0.05)$ enhanced upon treatment with compound 2 (at $100 \mu \mathrm{M})($ Fig. 4A). Although, no detectable levels of E-protein were evident in the same samples at MOI $=1$ infectious dose (Fig. 4B). It was noted that in HaCaT cells, under similar conditions (ZIKV infection, $\mathrm{MOI}=1$, for 24 hours; followed by compounds (1-4) treatments at 1,10 and $100 \mu \mathrm{M}$ for another 24 hours), ZIKV NS5 mRNA transcripts were significantly $(\mathrm{P}<0.05)$ increased upon treatment with compound $\mathbf{2}$, at both 10 and $100 \mu \mathrm{M}$ concentrations (Fig. 4C). Also, ZIKV E-protein loads were elevated upon treatment with compound 2 (at $100 \mu \mathrm{M}$ ) in comparison to the infected DMSO-treated controls (Fig 4D). Other compounds and their tested doses did not show any significant changes at either mRNA or protein levels (Fig. 4). We did not detected any ZIKV E-protein in infected and infected DMSOtreated controls due to very low infection with $\mathrm{MOI}=1$. Total protein profiles serve as loading controls (Fig. 4B \& 4D). These results suggest that treatment with $\mathrm{Cu}(\mathrm{II})$ conjugated compound 
2 post infection with ZIKV enhance viral burden, whereas without conjugation the same compound $\mathbf{1}$ did not showed any enhancement in ZIKV loads.

Since we did not find any detectable levels of E-protein in infected (untreated) or infected DMSO-treated controls at MOI $=1$ of ZIKV infection, we performed additional experiments with higher infectious doses of MOI $=5$. We first infected C6/36 cells or HaCaT cells with ZIKV at higher multiplication of infection of 5 for 24 hours, followed by treatments with compounds (1-4) at different doses of 1, 10, and $100 \mu \mathrm{M}$ concentrations. We detected E-protein in all compound treatments including compound $\mathbf{2}$, and there were no differences in comparison to the infected DMSO-treated controls (Fig. 5A). When HaCaT cells were infected with MOI = 5 of ZIKV in a similar manner, we detected E-protein in all samples including the infected (untreated) and infected DMSO-treated controls (Fig. 5B). We also included sodium salicylate (NaSal) compound that inhibits flavivirus replication [38] as control. NaSal-treated (5mM) cells showed inhibition of ZIKV replication and lower E-protein loads in both C6/36 cells and HaCaT cells (Fig. 5A \& 5B). Total protein profiles serve as loading controls in both C6/36 cells and HaCaT cells (Fig. 5A \& 5B).

\section{Pre-treatment with compounds 2 or 4 before infection with ZIKV enhance viral burden in both mosquito and human cells. To analyze if treatment with compounds before infection also enhance ZIKV replication in C6/36 and $\mathrm{HaCaT}$ cells, we first treated cells with compounds 1-4 (at concentrations of 1, 10 and $100 \mu \mathrm{M}$ ) for 24 hours and then infected with ZIKV $(\mathrm{MOI}=1)$ for another 24 hours. In C6/36 cells, treatment with $\mathrm{Cu}(\mathrm{II})$ or $\mathrm{Co}(\mathrm{III})$ conjugated- compounds 2 (10 and $100 \mu \mathrm{M})$ or $4(100 \mu \mathrm{M})$ significantly $(\mathrm{P}<0.05)$ increased ZIKV NS5 transcripts in}


comparison to the infected (untreated) or infected DMSO-treated controls (Fig. 6A). It was also noted that ZIKV E-protein loads were enhanced in C6/36 cells treated with compound 2 (10 and $100 \mu \mathrm{M})$ or $4(100 \mu \mathrm{M})$ (Fig. 6B). In HaCaT cells, inductions in ZIKV loads were also noted in treatments with both $\mathrm{Cu}(\mathrm{II})$ or $\mathrm{Co}(\mathrm{III})$ conjugated compounds 2 and 4 (100 $\mu \mathrm{M})$, respectively at $100 \mu \mathrm{M}$ concentration. In addition compound $\mathbf{1}(100 \mu \mathrm{M})$ also showed significant $(\mathrm{P}<0.05)$ induction in ZIKV NS5 loads in HaCaT cells (Fig. 6C). Immunoblotting showed that ZIKV Eprotein loads were enhanced upon treatment with compound $2(100 \mu \mathrm{M})$ in comparison to the infected DMSO-treated control (Fig. 6D). No significant changes were observed with other compounds and the tested doses (Fig. 6D). Total protein profiles serve as loading controls (Fig. 6C \& 6D). E-protein levels were since not detected in infected DMSO-treated or infected untreated controls, we next analyzed effect of these compounds on ZIKV infection with higher infectious doses of MOI $=5$. We treated C6/36 cells and HaCaT cells with compounds (1-4) at different doses of 1,10 , and $100 \mu \mathrm{M}$ concentrations for 24 hours and then infected with ZIKV at higher infectious dose $(\mathrm{MOI}=5)$ for another 24 hours. With increased infectious dosage both C6/36 cells and HaCaT cells, showed E-protein in all samples including the infected (untreated) and the infected DMSO-treated controls (Fig. 7). In C6/36 cells, no differences were noted between compounds $\mathbf{1 - 4}$, and in comparison to their respective infected DMSO-treated controls (Fig. 7A). However, a dose dependent enhancement of ZIKV loads was evident in HaCaT cells upon treatment with compounds 1-4 (Fig. 7B). Sodium salicylate treated (5mM) C6/36 cells and HaCaT cells serve as controls and show inhibition of ZIKV replication and lower E-protein levels (Fig. 7A \& 7B). Total protein profiles serve as loading controls in both C6/36 cells and HaCaT cells (Fig. 7A \& 7B). Collectively, these results suggest that $\mathrm{Cu}(\mathrm{II})$ or $\mathrm{Co}(\mathrm{III})$ conjugated compounds, enhance ZIKV and DENV2 infection in mosquito cells and human keratinocytes. 


\section{DISCUSSION}

Mosquito-borne diseases such as malaria, filariasis, arbovirus encephalitis and dengue are some of the major human health problems in tropical and subtropical countries. Recently, there has been an outbreak of ZIKV and Yellow Fever virus infections in the Americas. One of the potential interventions to combat mosquito-borne diseases is the continuous use of repellents in children and adults [7]. Our study suggests that use of $\mathrm{Cu}$ (II) or $\mathrm{Co}(\mathrm{III})$ containing metal centers in future preparations of food additives/repellents against mosquitoes may enhance replication and production of infectious viral particles of both DENV2 and ZIKV in the human cells upon transmission by the biting arthropods. Use of some insect repellents has been discouraged due to their adverse effects [3-8]. Safe use of alternatives like repellents of natural origin such as essential oils and their derived complex products has been preferred. Several studies have shown that plant based essential oils such as lemongrass; allspice oils, citral and other compounds are effective in controlling insect nuisance, mosquito bites and exhibit repelling properties [1,29,3941]. Repellent bioassays have revealed that the activity of lemon essential oils is due to the presence of citral component $[42,43]$. Our study has shown that thiosemicarbazone ligands derived from citral and 2-acetylethiazole and their conjugation with $\mathrm{Co}(\mathrm{III})$ or $\mathrm{Cu}(\mathrm{II})$, enhance ZIKV and DENV2 loads at both mRNA and protein levels, respectively. Testing of additional complexes 5 and $\mathbf{6}$ with 1, 10-phenanthroline ligands coordinated to Co(II) and Co(III) also showed similar increase in viral replication and DENV2 loads. Testing of "free" $\mathrm{Cu}(\mathrm{II})$ and Co(III) salts alone did not show any significant increase in DENV2 loads, suggesting no effects of free cations on viral replication. Our data also suggested that conjugation with these metal 
complexes might affect the antiviral or antimicrobial properties of such compounds. The reduced loads of IFN-beta suggested a diminished antiviral response in human cells (Supplementary Fig. $5 \mathrm{~A})$.

Several studies have shown that plant compounds have antiviral activities against dengue virus and other enveloped viruses [44-47]. However, conjugation of $\mathrm{Co}(\mathrm{III})$ or $\mathrm{Cu}$ (II) to such compounds may increase DENV2 loads in mosquito and HaCaT cells suggesting that both arthropod and human cells are susceptible to metal centers that may interfere and enhance DENV2 replication. In addition to human keratinocytes, human epithelial cells (HeLa cells) showed similar increase in DENV2 replication at $100 \mu \mathrm{M}$ doses, suggesting similar activity of the compound 4 in enhancing viral loads (Supplementary Fig. 5C). Primary cultures of mouse bone marrow derived dendritic cells infected with DENV2/ZIKV also suggested that compounds 2 and 4 increased viral replication at $100 \mu \mathrm{M}$ concentration in other mammalian cells (Fig. 3B \& 3C). Infection with ZIKV, followed by treatment with compounds also showed similar results with compound 2, where 10 and $100 \mu \mathrm{M}$ induced the ZIKV loads in both C6/36 cells and HaCaT cells (Fig. 4A \& 4C). Although, upon treatment with compound 2, the ZIKV E-protein loads were higher in $\mathrm{HaCaT}$ cells (Fig. 4C \& 4D), suggesting high susceptibility and less tolerance in presence of ZIKV with treatment of compounds conjugated to $\mathrm{Cu}$ (II) containing complexes. Increased infection with ZIKV $(\mathrm{MOI}=5)$ showed that the E-protein loads in both mosquito and human keratinocytes had no changes in comparison to the loads of E-protein from the infected (untreated) or infected DMSO-treated controls. This data revealed that with higher infectious dose of $\mathrm{MOI}=5$, and post-treatment of compounds after infection may moderately allow compounds to interfere in the enhancement of viral replication. 
Pre-treatments with compounds $\mathbf{2}$ and $\mathbf{4}$ followed by ZIKV infection showed increased viral loads (NS5 mRNA transcripts) in both mosquito and human keratinocytes (Fig. 6A \& 6C). However, the observation of higher loads of ZIKV E-protein in mosquito cells indicated greater replication of ZIKV in mosquito cells at all tested doses of compounds 2 and 4 (Fig. 6B). It was also noted that ZIKV loads in HaCaT cells (that were first treated with compounds $\mathbf{1}, \mathbf{2}$ and $\mathbf{4}$, followed by infection) were much higher when compared to the viral loads in HaCaT cells that were exposed to compounds after virus infection (Figs. 4C \& 6C). It is assumed that when these $\mathrm{Cu}(\mathrm{II})$ or $\mathrm{Co}(\mathrm{III})$ conjugated compounds $\mathbf{2} \& \mathbf{4}$ are applied to normal human skin, there are greater chances of encountering enhancement in the ZIKV replication upon bites from infected mosquitoes. It was noted that HaCaT cells treated with compounds 1-4 for 24 hours, then followed by ZIKV infection at higher infectious doses $(\mathrm{MOI}=5)$, showed a dose dependent increase of ZIKV E-protein levels with all tested compounds and their respective increasing doses (Fig. 7B). This data suggested that pre-exposure of human keratinocytes to these conjugated compounds might better enhance ZIKV loads when confronted through the infected mosquito bite. It is also intriguing to note that treatment with compound $\mathbf{2}$, followed by infection (with higher infectious dose of MOI = 5) with ZIKV, dramatically increased the viral loads in HaCaT cells (Figs. 7B), suggesting conjugation of $\mathrm{Cu}(\mathrm{II})$ or $\mathrm{Co}(\mathrm{III})$ complexes interference with ZIKV replication. Irrespective of the treatment procedures (infection followed by treatment with these compounds or pretreatment of compounds followed by infection) incubations lead to enhancement in DENV2/ZIKV loads in both arthropod and human cells. This enhancement of DENV2/ZIKV infection suggest that $\mathrm{Cu}$ (II) or $\mathrm{Co}(\mathrm{III})$ complexes in food additives or repellent sprays, lotions or any other forms might be disadvantageous on human cells and perhaps on other 
animals and aquatic environments. The mechanism of action of these compounds in enhancing DENV2/ZIKV loads in human keratinocytes is a future perspective. In summary, the present study shows that pre/post treatment with organic compounds containing $\mathrm{Cu}$ (II) or $\mathrm{Co}$ (III) metal complexes enhances ZIKV/DENV2 infection in mosquito, mouse and human cells. 


\section{ACKNOWLEDGEMENTS}

This work was supported by startup funds from Old Dominion University to HS. AAH work to generate compounds used in this study was supported by the Mississippi INBRE (P20RR016476), funded by the National Center for Research Resources, National Institutes of Health (NIH). AAH would like to thank the National Science Foundation (NSF) for the NSF CAREER Award, as this material is based upon work partially supported by the NSF under CHE-1431172 (Formerly CHE= 1151832). AAH would also like to thank Old Dominion University’s Faculty Proposal Preparation Program (FP3) and also the Old Dominion University start-up package that allowed for the successful generation of the tested compounds. The following reagent was obtained through BEI Resources, NIAID, NIH: Monoclonal AntiFlavivirus Group Antigen, Clone D1-4G2-4-15 (Produced in vitro), NR-50327. Authors declare no conflict of financial interests. 


\section{AUTHOR CONTRIBUTIONS}

SD, SK and HS performed experiments. MJC, AH, JFA (Jessa), AM and AAH prepared compounds tested in this study. CS and PJK provided bone marrow derived dendritic cells used in this study. SD, GN, AAH and HS discussed, analyzed and interpreted the data. HS planned, designed, coordinated and compiled the entire study. LH, ML and JFA provided important reagents. All authors edited and approved the manuscript. HS supervised overall investigations, wrote the paper. 


\section{REFERENCES}

1. Brown M, Hebert AA (1997) Insect repellents: an overview. J Am Acad Dermatol 36: 243249.

2. Katz TM, Miller JH, Hebert AA (2008) Insect repellents: historical perspectives and new developments. J Am Acad Dermatol 58: 865-871.

3. Briassoulis G, Narlioglou M, Hatzis T (2001) Toxic encephalopathy associated with use of DEET insect repellents: a case analysis of its toxicity in children. Hum Exp Toxicol 20: 8-14.

4. Clem JR, Havemann DF, Raebel MA (1993) Insect repellent (N,N-diethyl-m-toluamide) cardiovascular toxicity in an adult. Ann Pharmacother 27: 289-293.

5. Miller JD (1982) Anaphylaxis associated with insect repellent. N Engl J Med 307: 1341-1342.

6. Osimitz TG, Murphy JV (1997) Neurological effects associated with use of the insect repellent N,N-diethyl-m-toluamide (DEET). J Toxicol Clin Toxicol 35: 435-441.

7. Osimitz TG, Murphy JV, Fell LA, Page B (2010) Adverse events associated with the use of insect repellents containing N,N-diethyl-m-toluamide (DEET). Regul Toxicol Pharmacol 56: 93-99.

8. Snyder JW, Poe RO, Stubbins JF, Garrettson LK (1986) Acute manic psychosis following the dermal application of N,N-diethyl-m-toluamide (DEET) in an adult. J Toxicol Clin Toxicol 24: 429-439.

9. Rodriguez SD, Chung H, Gonzales KK, Vulcan J, Li Y, et al. (2017) Efficacy of SomeWearable Devices Compared with Spray-On Insect Repellents for the Yellow Fever Mosquito, Aedes aegypti (L.) (Diptera: Culicidae). J Insect Sci 17: 1-6. 
10. Antwi FB, Shama LM, Peterson RK (2008) Risk assessments for the insect repellents DEET and picaridin. Regul Toxicol Pharmacol 51: 31-36.

11. Isman MB (2006) Botanical insecticides, deterrents, and repellents in modern agriculture and an increasingly regulated world. Annu Rev Entomol 51: 45-66.

12. Rahman MA, Rahman MM, Reichman SM, Lim RP, Naidu R (2014) Heavy metals in Australian grown and imported rice and vegetables on sale in Australia: health hazard. Ecotoxicol Environ Saf 100: 53-60.

13. Seow YX, Yeo CR, Chung HL, Yuk HG (2014) Plant essential oils as active antimicrobial agents. Crit Rev Food Sci Nutr 54: 625-644.

14. Hadinegoro SRS (2012) The revised WHO dengue case classification: does the system need to be modified. Paediatric International Child Health 32.

15. World Health Organization. Geneva, Switzerland: WHO; 2009. Dengue: Guidelines for Diagnosis, Treatment, Prevention and Control.

16. Choumet V, Despres P (2015) Dengue and other flavivirus infections. Rev Sci Tech 34: 473$478,467-472$.

17. Murrell S, Wu SC, Butler M (2011) Review of dengue virus and the development of a vaccine. Biotechnol Adv 29: 239-247.

18. Coller BA, Clements DE (2011) Dengue vaccines: progress and challenges. Curr Opin Immunol 23: 391-398.

19. Aguiar M, Stollenwerk N, Halstead SB (2016) The Impact of the Newly Licensed Dengue Vaccine in Endemic Countries. PLoS Negl Trop Dis 10: e0005179.

20. Jelin AC, Salmeen K, Gano D, Burd I, Thiet MP (2016) Perinatal neuroprotection update. F1000Res 5. 
21. Klase ZA, Khakhina S, Schneider Ade B, Callahan MV, Glasspool-Malone J, et al. (2016) Zika Fetal Neuropathogenesis: Etiology of a Viral Syndrome. PLoS Negl Trop Dis 10: e0004877.

22. Singer M (2016) The spread of Zika and the potential for global arbovirus syndemics. Glob Public Health: 1-18.

23. Soundravally R, Sherin J, Agieshkumar BP, Daisy MS, Cleetus C, et al. (2015) Serum Levels of Copper and Iron in Dengue Fever. Rev Inst Med Trop Sao Paulo 57: 315-320.

24. Assuncao-Miranda I, Cruz-Oliveira C, Neris RL, Figueiredo CM, Pereira LP, et al. (2016) Inactivation of Dengue and Yellow Fever viruses by heme, cobalt-protoporphyrin IX and tin-protoporphyrin IX. J Appl Microbiol 120: 790-804.

25. Beck MA (2001) Antioxidants and viral infections: host immune response and viral pathogenicity. J Am Coll Nutr 20: 384S-388S; discussion 396S-397S.

26. Gilling DH, Kitajima M, Torrey JR, Bright KR (2014) Mechanisms of antiviral action of plant antimicrobials against murine norovirus. Appl Environ Microbiol 80: 4898-4910.

27. Koch C, Reichling J, Schneele J, Schnitzler P (2008) Inhibitory effect of essential oils against herpes simplex virus type 2 . Phytomedicine 15: 71-78.

28. Minami M, Kita M, Nakaya T, Yamamoto T, Kuriyama H, et al. (2003) The inhibitory effect of essential oils on herpes simplex virus type-1 replication in vitro. Microbiol Immunol 47: $681-684$.

29. Reichling J, Schnitzler P, Suschke U, Saller R (2009) Essential oils of aromatic plants with antibacterial, antifungal, antiviral, and cytotoxic properties--an overview. Forsch Komplementmed 16: 79-90. 
30. Lewis NA, Liu F, Seymour L, Magnusen A, Erves TR, et al. (2012) Synthesis, characterization, and preliminary studies of vanadium(IV) complexes with a Schiff base and thiosemicarbazones as mixed-ligands. Eur J Inorg Chem 2012: 664-677.

31. Sandhaus S, Taylor R, Edwards T, Huddleston A, Wooten Y, et al. (2015) A novel copper(II) complex identified as a potent drug against colorectal and breast cancer cells and as a poison inhibitor for human topoisomerase II $\alpha$. Inorg Chem Commun submitted.

32. Kashiwabara K, Igi K, Douglas BE (1976) Circular dichroism of cobalt(III) complexes of the type cis- $\left[\mathrm{CoN}_{2} \mathrm{O}_{4}\right]$ and cis- $\left[\mathrm{CoN}_{4} \mathrm{O}_{2}\right]$ containing acetylacetonate ion, 2,2'-bipyridine and 1,10-phenanthroline. Bull Chem Soc Jpn 49: 1573-1578.

33. Ye B-H, Chen X-M, Zeng T-X, Ji LN (1994) Synthesis, crystal structures and spectroscopic characterization of $\left[\mathrm{Co}(\text { phen })_{2}(\mathrm{gly})\right] \mathrm{Cl}_{2} \cdot 4 \mathrm{H}_{2} \mathrm{O}$ and $\left[\mathrm{Co}(\text { phen })_{2}\left(\mathrm{H}_{2} \mathrm{O}\right)_{2}\right]\left(\mathrm{NO}_{3}\right)_{3} \cdot 2 \mathrm{H}_{2} \mathrm{O}$. Polyhedron 13: 2185-2191.

34. Lee CaA, F.C (1984) Electron Exchange between C (phen) + Adsorbed on Graphite and $\mathrm{Cu}($ phen)22+ in Solution Inorg Chem 23: 837-844.

35. Giuliana Grassini-Strazza MS (1980) Preparation and Characterization of Cobalt(III)Bipyridine and Phenanthroline Complexes Inorganica Chimica Acta 44: L295-L297.

36. Sultana H, Foellmer HG, Neelakanta G, Oliphant T, Engle M, et al. (2009) Fusion loop peptide of the West Nile virus envelope protein is essential for pathogenesis and is recognized by a therapeutic cross-reactive human monoclonal antibody. J Immunol 183: 650-660.

37. Faye O (2013) Quantitative real-time PCR detection of Zika virus and evaluation with fieldcaught mosquitoes. Virology Journal 10. 
38. Liao CL, Lin YL, Wu BC, Tsao CH, Wang MC, et al. (2001) Salicylates inhibit flavivirus replication independently of blocking nuclear factor kappa B activation. J Virol 75: 78287839.

39. Choi WS, Park BS, Ku SK, Lee SE (2002) Repellent activities of essential oils and monoterpenes against Culex pipiens pallens. J Am Mosq Control Assoc 18: 348-351.

40. Gillij YG, Gleiser RM, Zygadlo JA (2008) Mosquito repellent activity of essential oils of aromatic plants growing in Argentina. Bioresour Technol 99: 2507-2515.

41. Pisseri F, Bertoli A, Pistelli L (2008) Essential oils in medicine: principles of therapy. Parassitologia 50: 89-91.

42. Hsu WS, Yen JH, Wang YS (2013) Formulas of components of citronella oil against mosquitoes (Aedes aegypti). J Environ Sci Health B 48: 1014-1019.

43. Giatropoulos A, Papachristos DP, Kimbaris A, Koliopoulos G, Polissiou MG, et al. (2012) Evaluation of bioefficacy of three Citrus essential oils against the dengue vector Aedes albopictus (Diptera: Culicidae) in correlation to their components enantiomeric distribution. Parasitol Res 111: 2253-2263.

44. Astani A, Reichling J, Schnitzler P (2011) Screening for antiviral activities of isolated compounds from essential oils. Evid Based Complement Alternat Med 2011: 253643.

45. Gomez LA, Stashenko E, Ocazionez RE (2013) Comparative study on in vitro activities of citral, limonene and essential oils from Lippia citriodora and L. alba on yellow fever virus. Nat Prod Commun 8: 249-252.

46. Meneses R, Ocazionez RE, Martinez JR, Stashenko EE (2009) Inhibitory effect of essential oils obtained from plants grown in Colombia on yellow fever virus replication in vitro. Ann Clin Microbiol Antimicrob 8: 8. 
47. Ocazionez RE, Meneses R, Torres FA, Stashenko E (2010) Virucidal activity of Colombian Lippia essential oils on dengue virus replication in vitro. Mem Inst Oswaldo Cruz 105: 304-309. 


\section{FIGURE LEGENDS}

Figure 1. Treatment with organic compounds post infection enhances dengue virus loads. Q-PCR and immunoblotting analysis showing the DENV2 capsid transcripts or envelope Eprotein loads in C6/36 mosquito cells (A \& B) or human keratinocytes (HaCaT cells) (C \& D) infected with DENV2 $(\mathrm{MOI}=1)$ for 24 hours followed by treatment with compounds $\mathbf{1 - 4}$ at different concentrations $(1,10$ and $100 \mu \mathrm{M})$ for another 24 hours, respectively. DENV2 capsid mRNA transcript levels (A \& C) were determined by Q-PCR upon treatment with compounds in comparison to the infected-DMSO controls. UT indicates untreated cells; M shows marker lane and $\mu \mathrm{M}$ means micro molar. Uninfected (UI) or infected (I) cells treated with DMSO are included as controls. DENV2 E- protein was detected in panels B \& D and upper band indicates glycosylated form. Total protein profiles are shown as loading control and not for comparison. The differences in protein profiles are due to use of Colloidal Coomassie blue staining in panels with compounds 1 and 4 and Coomassie blue R-250 staining solution in panels with compounds 2 and 3. Statistics was performed using the Student's two-tailed test. The $P<0.05$ is indicated with an asterisk to show significance in comparison to DMSO-treated control and error bars indicate standard deviation.

\section{Figure 2. Treatment with compounds 2 and 4 increase DENV2 infectious titers and viral} plaques. Virus titration assays in mosquito (A) and $\mathrm{HaCaT}(\mathrm{B})$ cells showing percentages of infected cells upon 24-hours treatment with compounds (1-4) at doses of 1, 10 and $100 \mu \mathrm{M}$, followed by infection with DENV2 (MOI 1) for another 24 hours. Percentage of infected cells were analyzed from eight different microscope fields in comparison to the infected-DMSO- 
treated controls and plotted as percentages. (C) Plaque formation assay performed in Vero cells treated with compounds $\mathbf{1 - 4}$ at $100 \mu \mathrm{M}$ for 24 hours followed by infection with DENV2 (MOI 1) for 2 hours and incubation for another 5 days to form plaques are shown. A representative image of a 6-well plate with plaques from different groups is shown. Plaques from compounds treated groups were compared to the infected-DMSO-treated control. Ruler at the bottom determines the scale for the plaques from the representative image. (D) Quantitative assessment of number of plaques from compound (1-4) treated $(100 \mu \mathrm{M})$ and infected-DMSO-treated is shown. Representative data from two independent experiments is shown. $\mathrm{P}$ value determined by Student's two-tail $t$ test is shown.

Figure 3. Treatment of compounds enhances DENV2 and ZIKV loads in primary cultures of mouse bone marrow derived dendritic cells.

Q-PCR analysis showing DENV2 loads in primary cultures of mouse bone marrow derived dendritic cells showing DENV2 (A) and ZIKV loads (B). 1 x $10^{5}$ Cells were infected with MOI $=1$ of either DENV2 or ZIKV for 24 hours and followed by treatments with compounds $\mathbf{1 - 4}$ at different concentrations $(1,10$ and $100 \mu \mathrm{M})$ for another 24 hours, respectively. DENV2 capsid mRNA transcript (A) and ZIKV NS5 mRNA transcript levels (B) were determined by Q-PCR upon treatment with compounds in comparison to the infected-DMSO controls. UT indicates untreated cells and $\mu \mathrm{M}$ means micro molar. Uninfected (UI) or infected (I) cells treated with DMSO are included as controls. ns indicates not significant. Statistics was performed using the Student's two-tailed test. The $\mathrm{P}<0.05$ is indicated with an asterisk to show significance in comparison to DMSO-treated control and error bars indicate standard deviation. 
Figure 4. ZIKV loads are induced following post-treatment with organic compounds. QPCR and immunoblotting analysis showing the ZIKV NS5 mRNA or E-protein loads in mosquito C6/36 cells (A \& B) or human keratinocytes (HaCaT cells) (C \& D) infected with ZIKV $(\mathrm{MOI}=1)$ for 24 hours followed by treatment with compounds 1-4 at different concentrations $(1,10$ and $100 \mu \mathrm{M})$ for another 24 hours, respectively. ZIKV NS5 mRNA transcript levels (A \& C) were determined by Q-PCR upon treatment with compounds in comparison to the infected-DMSO controls. ZIKV E- protein was detected in panels B \& D. Total protein profiles serves, as loading controls are not shown for comparison. UT indicates untreated cells and (UI) or (I) indicates uninfected or infected cells, respectively. M shows marker lane. Cells infected and treated with DMSO are included as controls. ns indicates not significant. Statistics was performed using the Student's two-tailed test. The $\mathrm{P}<0.05$ is indicated with an asterisk to show significance in comparison to DMSO-treated control and error bars indicate standard deviation.

Figure 5. ZIKV loads are induced with higher infection following post-treatment with organic compounds. Immunoblotting analysis showing the ZIKV E- protein in C6/36 cells (A) or human keratinocytes (HaCaT cells) $(\mathrm{B})$ infected with ZIKV $(\mathrm{MOI}=5)$ for 24 hours followed by treatment with compounds 1-4 at different concentrations (1, 10 and $100 \mu \mathrm{M})$ for another 24 hours, respectively. ZIKV E- protein was detected in panels B \& D and upper band indicates glycosylated form. Total protein profiles serve as loading controls. UT indicates untreated cells and (UI) or (I) indicates uninfected or infected cells. M shows marker lane. Cells infected and DMSO-treated are included as controls. 
Figure 6. Pre-treatment with organic compounds further enhanced ZIKV loads. Q-PCR and immunoblotting analysis showing the ZIKV NS5 mRNA or envelope E-protein loads in C6/36 cells (A \& B) or HaCaT cells (C \& D) treated with compounds 1-4 at different concentrations (1, 10 and $100 \mu \mathrm{M}$ ) for 24 hours followed by infection with ZIKV (MOI 1) for another 24 hours, respectively. ZIKV NS5 mRNA transcript levels (A \& C) were determined by Q-PCR upon treatment with compounds in comparison to the infected-DMSO controls. UT indicates untreated cells and ns indicate not significant. Uninfected (UI) or infected (I) cells treated with DMSO are included as controls. M shows marker lane. Total protein profiles are not shown for comparison and serve as loading controls. Statistics was performed using the Student's two-tailed test. The $\mathrm{P}<0.05$ is indicated with an asterisk to show significance in comparison to DMSO-treated control and error bars indicate standard deviation.

Figure 7. ZIKV loads are induced with higher infection dose following pre-treatment with organic compounds. Immunoblotting analysis showing the ZIKV E- protein in C6/36 mosquito cells (A) or human keratinocytes (HaCaT cells) (B) that were treated with compounds 1-4 at different concentrations $(1,10$ and $100 \mu \mathrm{M})$ for 24 hours and followed by infection with ZIKV $(\mathrm{MOI}=5)$ for another 24 hours, respectively. ZIKV E- protein was detected in panels B \& D and upper band indicates glycosylated form. Total protein profiles serve as loading controls and $\mathrm{M}$ indicates marker lane. UT indicates untreated cells and (UI) or (I) indicates uninfected or infected cells. Cells infected and treated with DMSO are included as controls. 


\section{FIGURES}
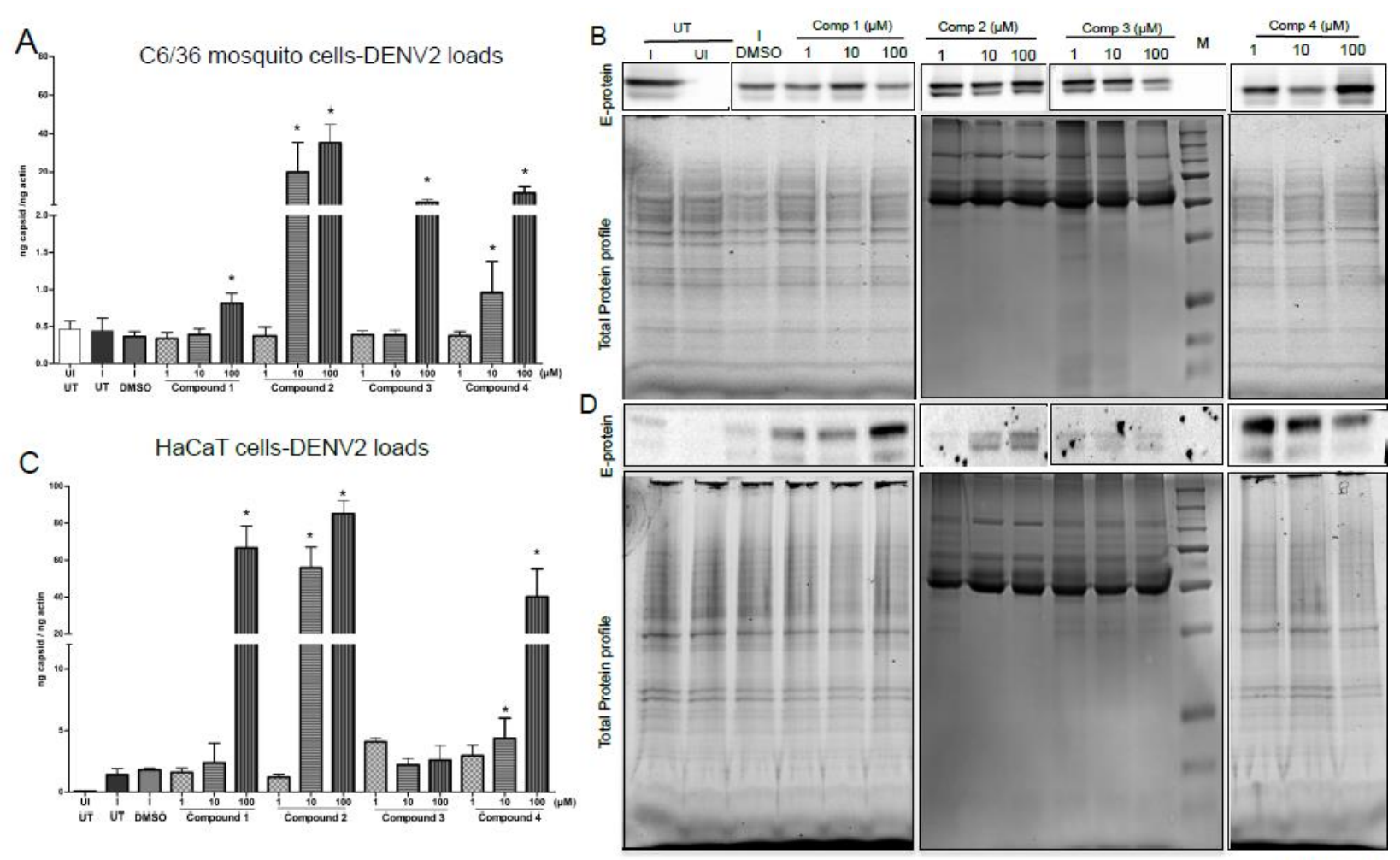

Figure 1 

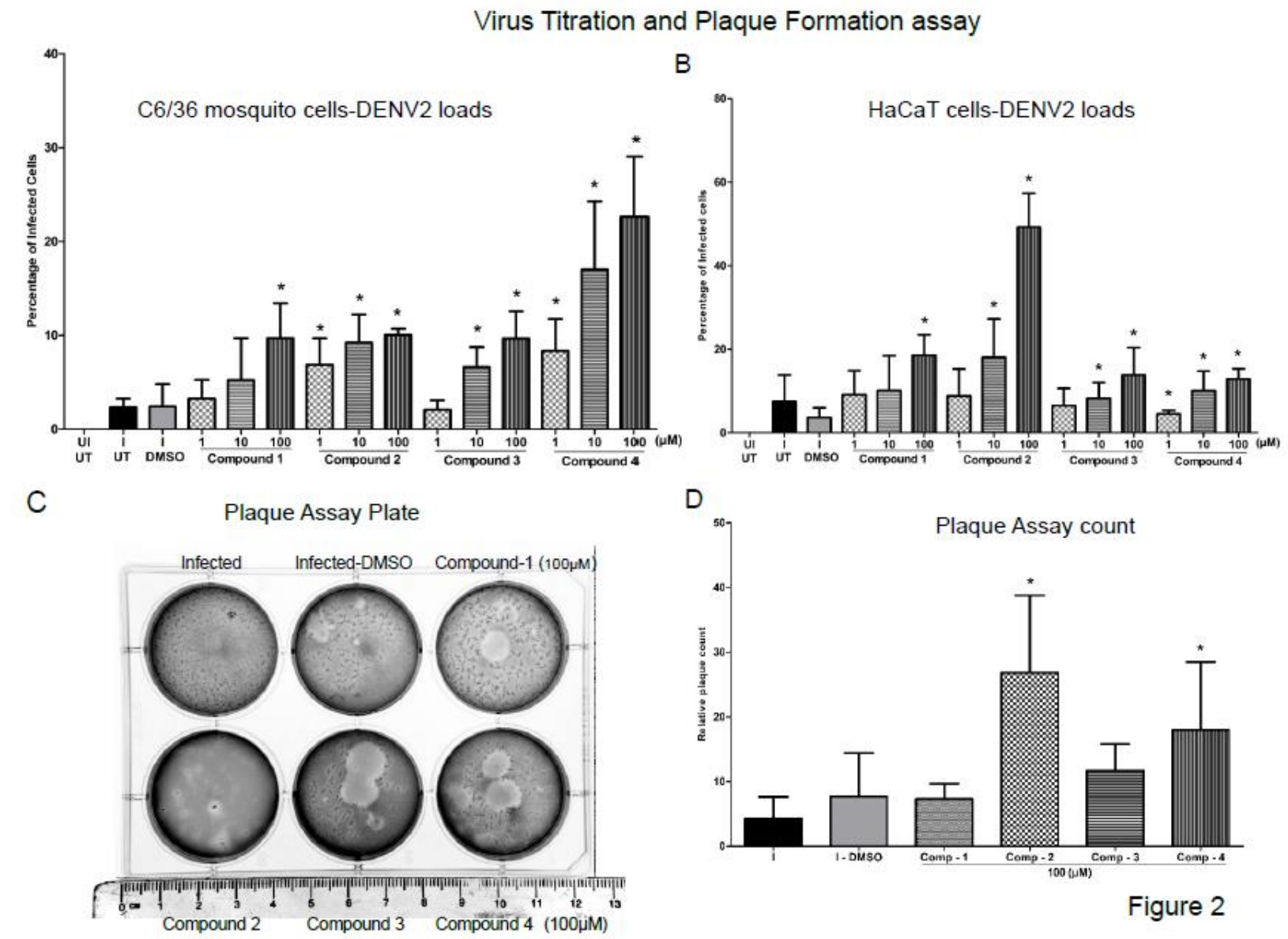

D

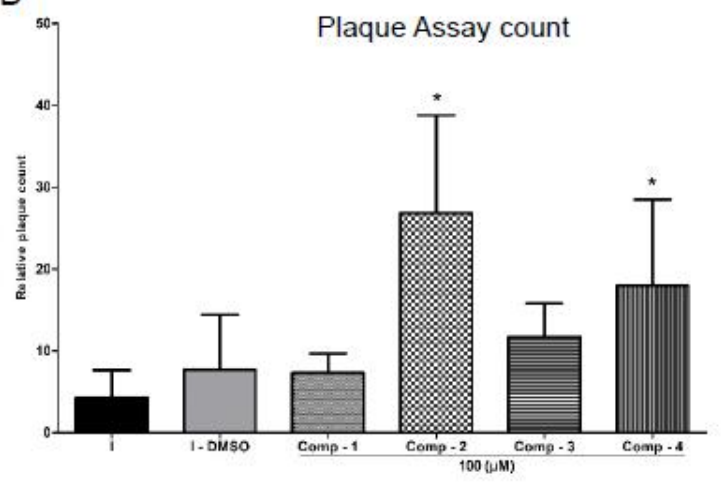

Figure 2 

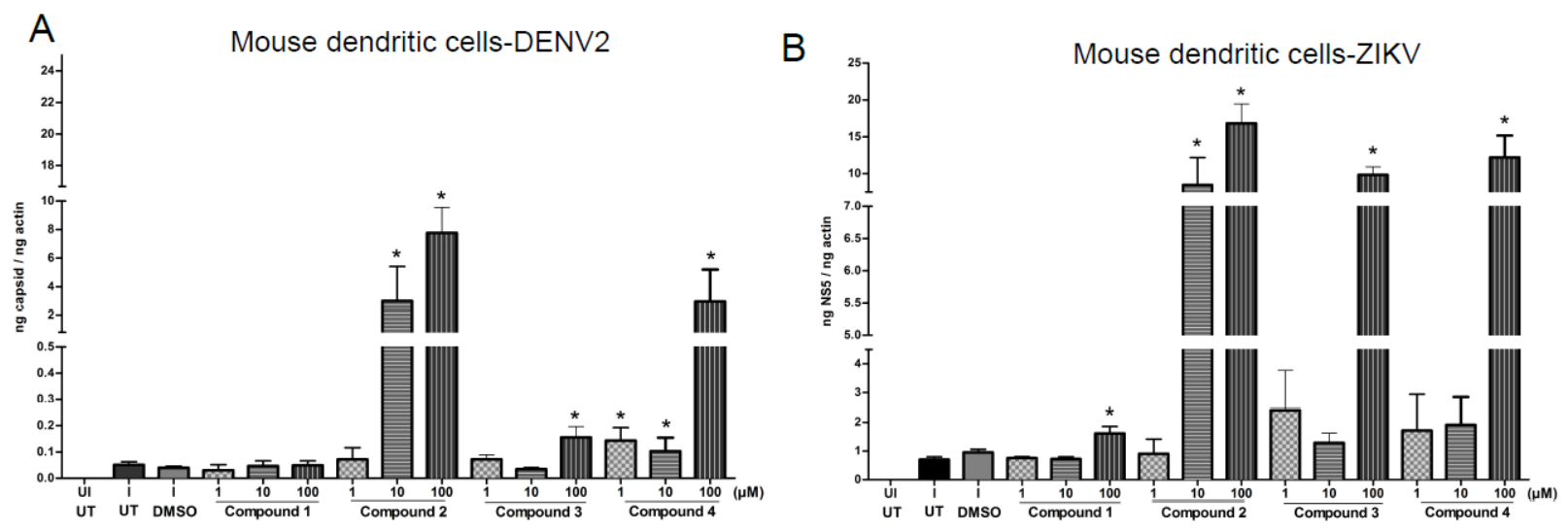

Figure 3 

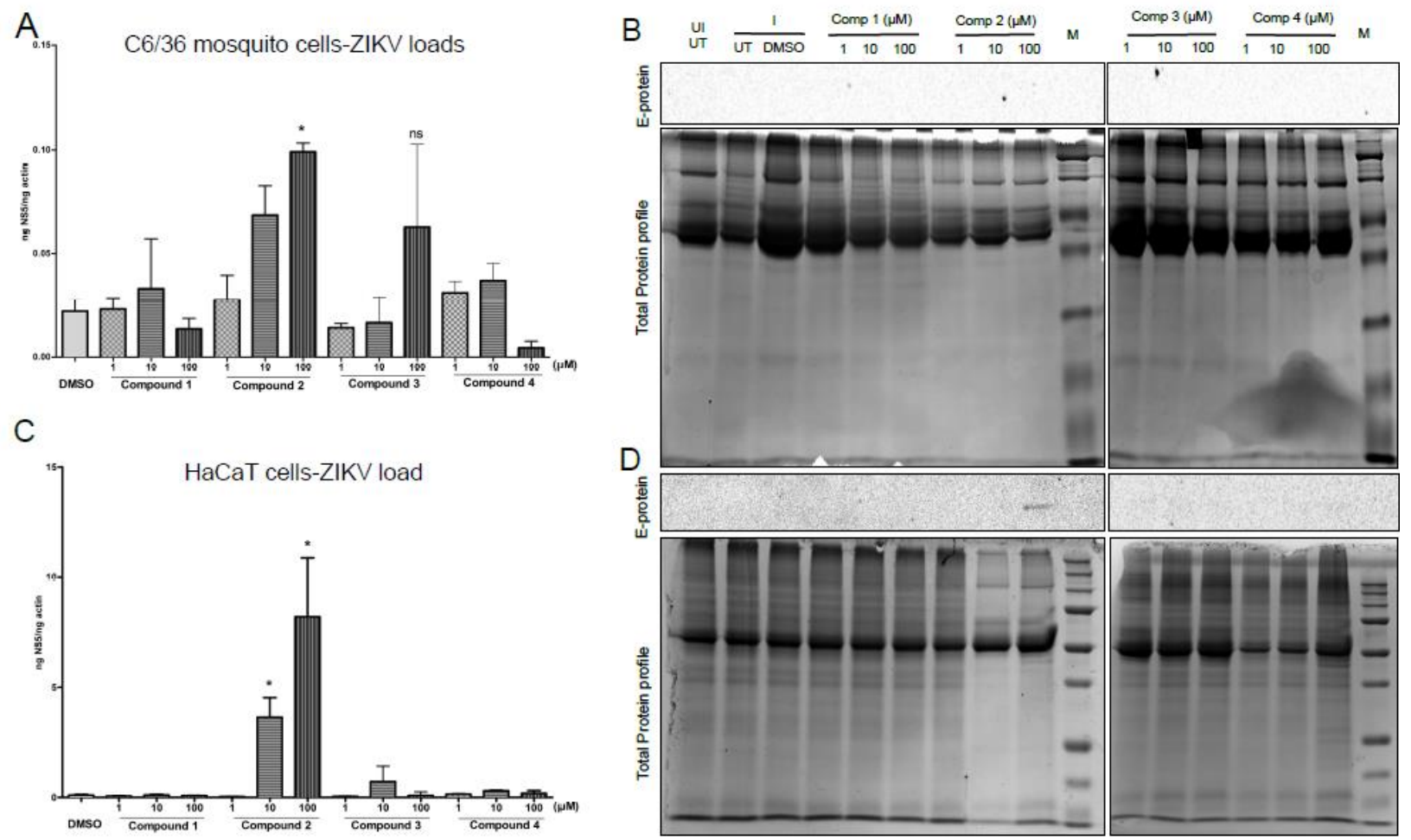

Figure 4 


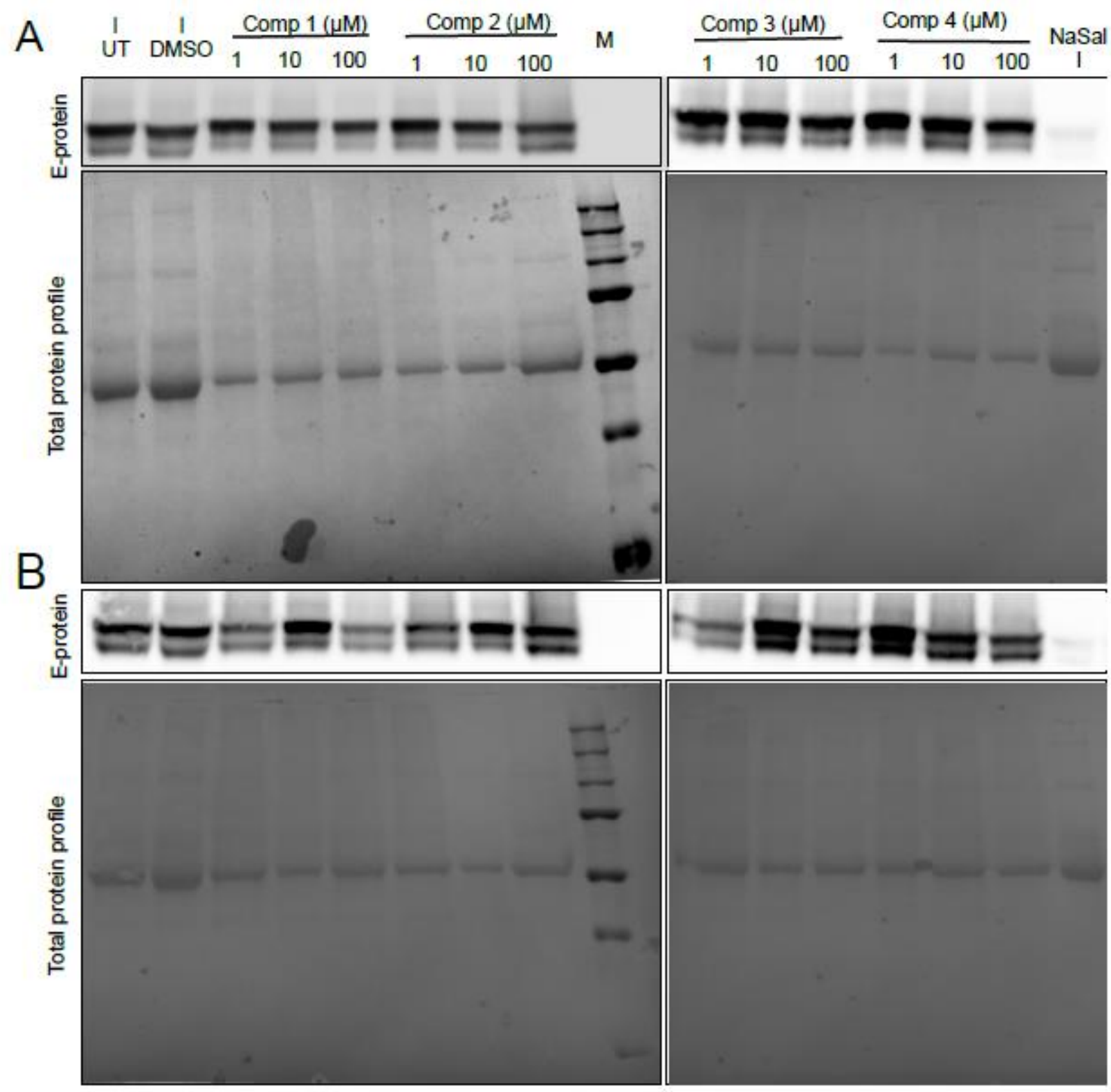

Figure 5 

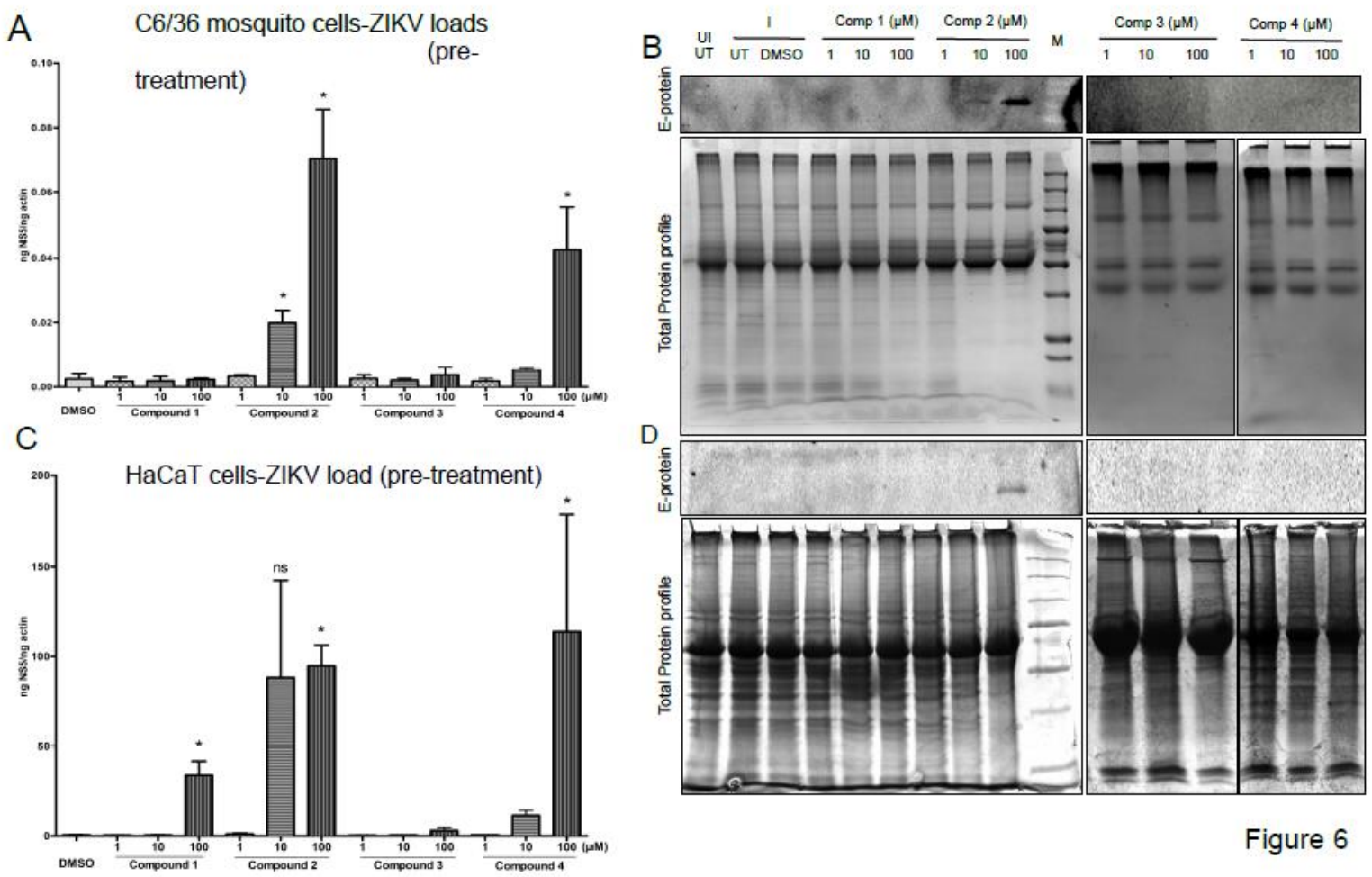

Figure 6 


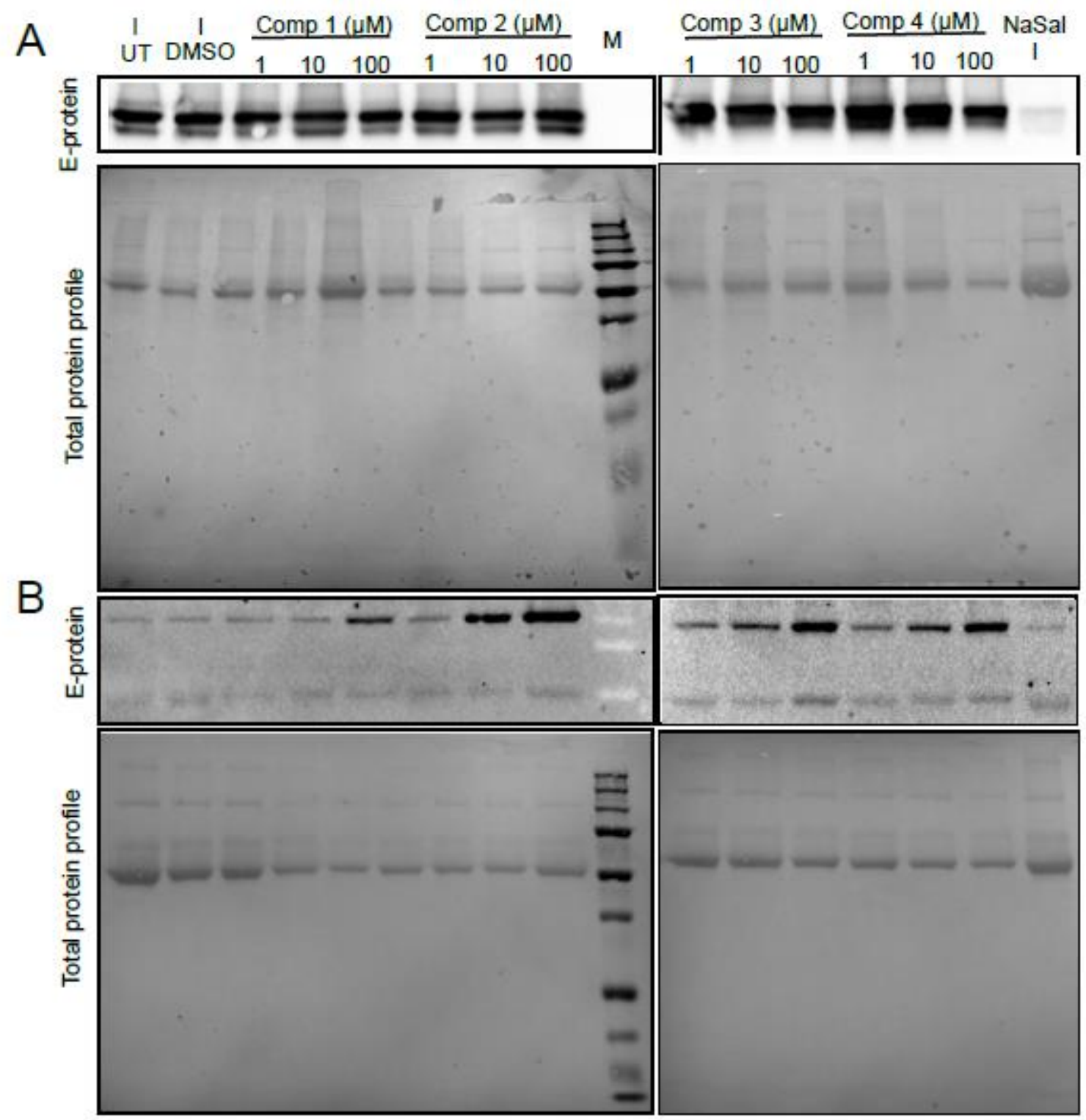

Figure 7 


\section{HIGHLIGHTS}

Mosquito-borne diseases are of great concern to the mankind. Use of chemicals/repellents against mosquito bites and transmission of microbes has been the topic of interest from many years. Here, we show that thiosemicarbazone ligand(s) derived from 2-acetylethiazole or citral or 1,10-phenanthroline upon conjugation with copper(II) or cobalt(III) metal centers enhances dengue virus (serotype 2; DENV2) and/or Zika virus (ZIKV) infections in mosquito, mouse and human cells. Enhanced ZIKV/DENV2 capsid mRNA or envelope protein loads were evident in mosquito cells and human keratinocytes, when pre-treated with compounds before/after infections. Also, treatment with copper(II) or cobalt(III) conjugated compounds increased viral titers and number of plaque formations. These studies suggest that conjugation of compounds in repellents/essential oils/natural products/food additives with copper(II) or cobalt(III) metal centers may not be safe, especially in tropical and subtropical places, where several dengue infection cases and deaths are reported annually or in places with increased ZIKV caused microcephaly. 